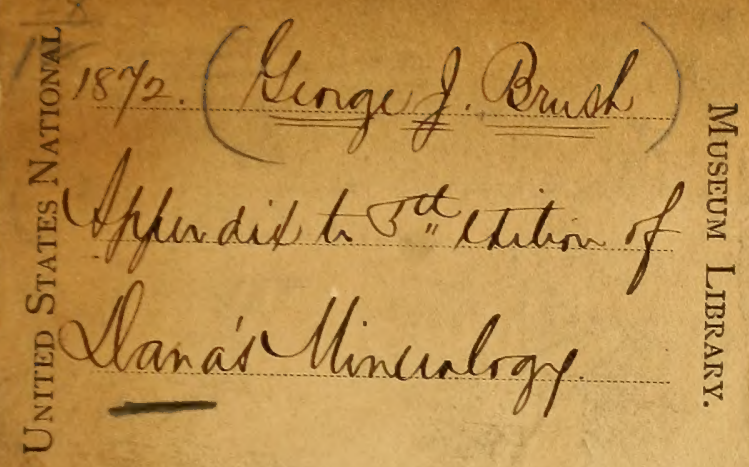

QE

372

D177bX

NMAH 


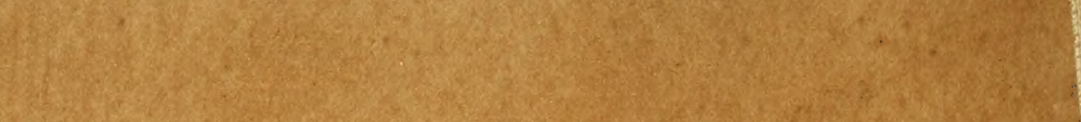

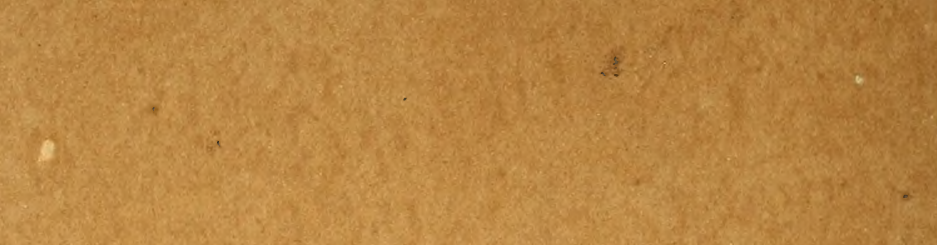


APPENDIX

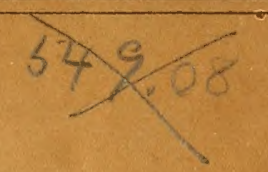

TO THE

-

FIFTH EDITION

of

\section{DANA'S MINERALOGY:}

GEORGE J. BRUSH,

PROFESSOR OF MONERALOGY IN TEE SHEFYHELD SCIENTIFIC SCHOOL OF YALE COLLEGE.

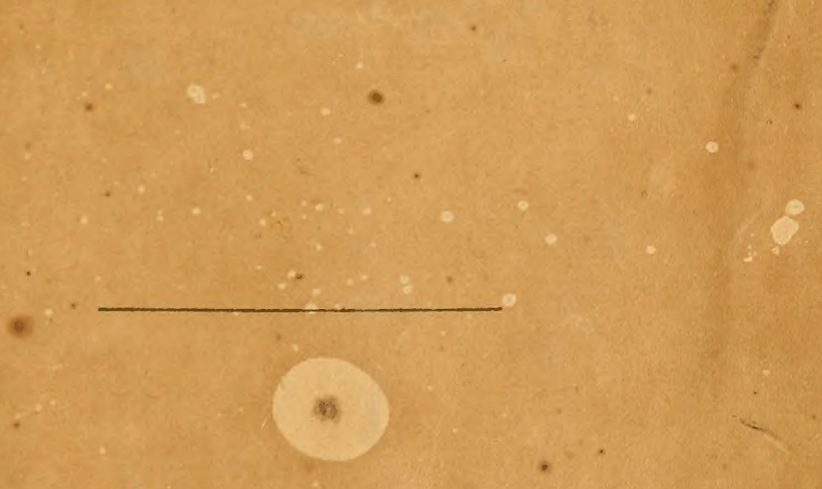

NEW YORK:

J QTH W ILEY \& SON,

15 ASTOR PLACE.

1872. 




\section{APPENDIX}

TO THE

-.

FIFTH EDITION

oF

\section{DANA'S MINERALOGY,}

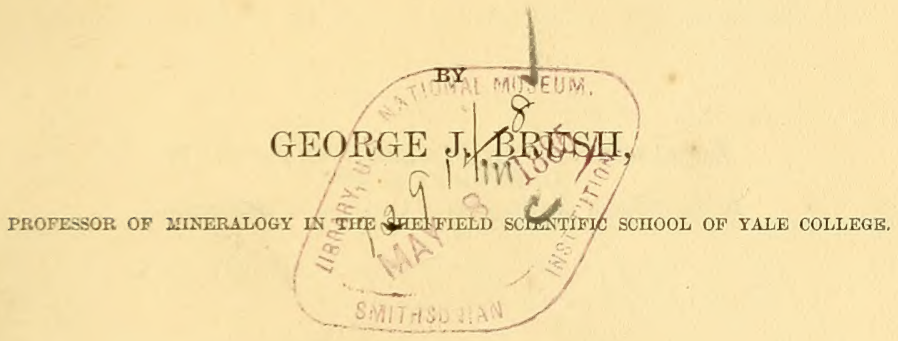

NEW YORK:

JOHN WILEY \& SON,

15 ASTOR PLACE. 
Entered according to Act of Congress, in the year 1872 , by JOHN WILEY \& SON,

In the Office of the Librarian of Congress, at Washington.

Poole \& Maclauchlan, Printers,

205-213 East Truclfth Street,

New York. 


\section{PREFATORY NOTE.}

THIS Appendix, prepared with the co-operation of Professor DANA, is intended as one of a series to be published from time to time. It includes descriptions of 87 minerals announced as new, and also some important facts regarding a few old species, published since the appearance of the Mineralogy in 1868.

An alphabetical arrangement is adopted for convenience of reference. The species included, arranged according to the general subdivisions in the classification of minerals, are as follows:-

\section{Native Elements.}

\section{Diamond.}

1 2. Maldonite.

2. Sulphids, Arsenids, etc.

3. Arsenical Cobalt, Einfach-Arsenik-Cobalt. |11. Klaprotholite.

4. Beyrichite.

5. Diaphorite.

6. Dyscrasite: Stibiotriargentite, Stibiohexargentite.

7. Epiboulangerite.

8. Epigenite.

9. Glaucopyrite.

10. Julianite.

12. Metacinnabarite.

13. Orileyite.

14. Osbornite.

15. Polyargyrite.

16. Rionite.

17. Tellurwismuthsilber.

18. Wolfachite.

19. Sylvanite.

3. Chlorids, Fluorids.

20. Nadorite, $\mathrm{Sb}, \mathrm{Pb}, \mathrm{Cl}, \mathrm{O}$.

21. Nantokite, $\mathrm{Cu}^{2} \mathrm{CI}$.

24. Chrompicotite (Spinel group).

25. Ilsemannite, $\dot{\mathrm{M}} \mathrm{O}+4 \ddot{\mathrm{M}} \mathrm{o}$.

26. Jacobsite (Spinel group).

27. Lithiophorite (near Asbolan).
22. Ralstonite, $\mathrm{Al}, \mathrm{Fl}, \mathrm{H}$.

23. Sellaite, Mg Fl.

4. Oxyds.

28. Namaqualite (near Hydrotalcite).

29. Rabdionite.

30. Brookite.

31. Tridymite.

\section{Anhydrous Silicates.}

32. Amblystegite (Hypersthenite).

33. Aspidolite (Mica Group).

34. Asteroite (Pyroxene).

35. Barettite.
36. Bismutoferrite.

37. Hortonolite (Chrysolite Group).

38. Monzonite.

39. Roepperite (Chrysolite Group). 


\section{Hydrous Silicates.}

40. Antillite (near Serpentine).

41. Aquacreptite (near Hydrophite).

42. Cyanochalcite (near Chrysocolla).

43. Diabantachronnyn (Chlorite Group).

44. Ephesite.

45. Epiphanite (near Eukamptite).

46. Euralite (near Delessite).

47. Gümbelite (near Pinite).

48. Hallite.

49. Hypochlorite.

50. Iviotite.

51. Milarite (a Zeolite ?).

\author{
52. Næsumite. \\ 53. Nigrescite. \\ 54. Plumballophane. \\ 55. Restormelite. \\ 56. Reissite (near Monophane). \\ 57. Talcosite. \\ 58. Uranotil. \\ 59. Westanite (near Wörthite). \\ 60. Lesleyite. \\ 61. Pattersonite. \\ 62. Selwynite.
}

\section{Tantalates, Columbates.}

63. Ferroilmenite (Columbite).

| 64. Kochelite (near Fergusonite).

8. Phosphates, Arsenates, etc.

65. Andrewsite.

66. Coruleolactite.

6\%. Durangite.

68. Guano Phosphates.

69. Isoclasite.

70. Kollophan.

71. Lime-Wavellite.
72. Lünebergite.

73. Montebrasite (Amblygonite).

74. Redondite.

75. Sarcopside (Triplite).

76. Trögerite.

77. Walpurgite.

78. Zepharovichite.

\section{Borates.}

79. Sussexite.

| 80. Winkworthite.

10. Tungstates, Molybdates, Vanadates.

81. Wolframite.

82. Eosite.

85. Guano Sulphates.

86. Caledonite.

87. Simonyite.

90. $\bar{B}$ astnaesite (Hamartite).
83. Pucherite.

84. Vanadiolite.

11. Sulphates, Chromates.

88. Laxmannite.

89. Phosphochromite.

12. Carbonates, Oxalates.

| 91. Guano-oxalates.

13. Carbo-hydrogen Compounds.

92. Ambrosine.

93. Rosthornite.
94. Trinkerite.

95. Wollongongite. 


\section{APPENDIX I.*}

\section{Minerals deseribed as nero species.}

411. Antitite. - A name given br C. U. Shepard to a substance he considers to be a hrdrated bronzite. It occurs both massire and crystalline, presenting minute coppery lamini, with a filurous clearage. H. $=3 \cdot \tilde{\mathrm{j}}-1 . \mathrm{G} .=2 \cdot 5 \%$. Color dark greenish-brown. An

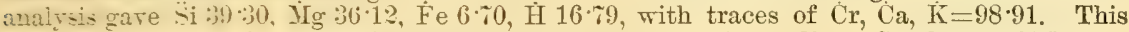
composition approaches that of serpentine or deweylite. (Appendix to Catalogue of Meteorites, Amherst, Mass., January 1, 1872).

235. Aubltstegite.-G. vom Rath, Pogg. Ann., exxxviii. 531.

Orthorhombic: $i-\bar{i} \wedge I=135 \bar{j}^{\circ} 50^{\prime}, i-\bar{\imath} \wedge 1-\bar{z}=119^{\circ} 26^{\prime}, \frac{1}{4}-\breve{\imath} \wedge \frac{1}{4}-\check{\imath}=163^{\circ} 47^{\prime}, i \check{\imath} \wedge \frac{1}{4} \check{\imath}=$ $9 S^{\prime}$ ti'. Clearage not observed. Hardness nearly equal to quartz. G. $=3 \cdot 454$. Lustre adamantine-ritreous. Color brown to reddish-brown. Streak greenish-gray. Translucent. Fracture conchoidal. Analysis, G. vom Rath (1.c.) :

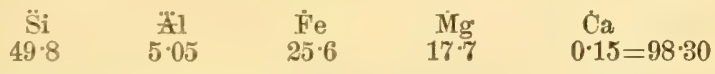

Only half a gram was available for analysis, and the state of oxydation of the iron was not determined. B. B. difficultly fusible without intumescence to a black glass. Not decompres? 1,5 muriatic acid. Found at Lake Laach. Amblystegite is closely related to hrlifi-thenite in form and chemical composition. V. $\mathrm{v}$. Lang has recently discovered crystal- of 37 uersthenite in the meteorite of Breitenbach which give the same planes as amblystegrite. and rom Rath now announces (Jahrb. Min., 1871, 642) the identity of his supposed new species with hypersthenite.

799 B. Aurrosme. C. U. Shepard, Rural Carolinian, i. p. 311.

In rounderl masses. Color yellowish to clove-brown. Fracture conchoidal. Lustre, resinous. Becomes electric on friction. Jielts at about $460^{\circ} \mathrm{F}$. to a clear yellowish liquid; siffeas at a lower temperature. Gives off "succinic acid" before melting; on fusion gives an agreeable halsam odor, unlike that from the resins of ordinary pines, and a dark brown nonvolatile fuil remains as long as the melting heat is kept up. Combustible, leaves no ash. Srolulile frr the most part in oil of turpentine, alcohol, ether, and chloroform, as also in potash. Fround in the phosphatic beds near Charleston, S. C., having originated in the eocene formation.

ANdrewsite, N. B. Maskelyne, Chem. News, xxiv. 99.

In globular disks with radiated structure resembling wavellite. G. $=3 \cdot 475$. Color bluishgreen. Composition, a bydrous phosphate of iron and copper. An average of four determinations gare 10.82 per cent. of copper; and according to Maskelyne the analyses (not griven in the article quoted) "justify the formula? ( ever. a rortion of the ferric phosphate is replaced by ferrous phosphate, as in vivianite is frequently the case with the two phosphates."

rocurs in Cromwall on a quartzose veinstone associated with limonite and göthite, and interpenetrated with a mineral resembling, if not identical with, dufrenite. Requires further description.

71 A. Arsanirril, colurlt. Cnder the title Einfach-arsenile-cobralt, Kenngott calls attention to a minera! which arnears to be hexagonally crystallized arsenid of cobalt, occurring with barite and quartz at Bieber (Jahrb. Min., 1869, 754).

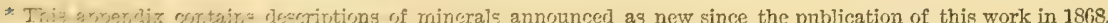

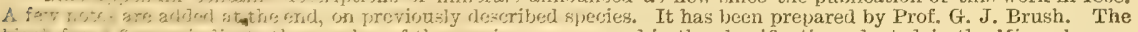
r. NEW Haves, March 1, 1872. 
288 A. Asprdolite-_Aspidolith, $F$. v. Kobell, Ber. Ak. München, March 6, 1869.

Orthorhombic: in prisms giving approximatively $120^{\circ}$ and $60^{\circ}$. The smaller sides show reëntering angles from twinning, or an aggregation of several crystals, giving the base an oval shield-like appearance. Optically biaxial, with the divergence angle $11^{\circ} 55^{\prime}$ for the red rays. Bisectrix normal to cleavage plane. $\mathrm{H} .=1-2 . \quad \mathrm{G} .=2 \cdot 72$. Lustre pearly, submetallic. Color olive-green, in thin leaves brownish-yellow. Foliated, leaves flexible, but not elastic. An analysis afforded von Kobell:

$\begin{array}{ccccccc}\stackrel{\mathrm{Si}}{\mathrm{i}} & \dddot{\mathrm{Al}} & \dot{\mathrm{Mg}} & \dot{\mathrm{F} e} & \stackrel{\mathrm{Na}}{\mathrm{K}} & \dot{\mathrm{K}} \\ 46 \cdot 44 & 10 \cdot 50 & 26 \cdot 30 & 9 \cdot 00 & 4 \cdot 77 & 2 \cdot 52 & 1 \cdot 33=100 \cdot 86\end{array}$

The oxygen ratio of $\hat{R}$, $\stackrel{*}{*}$, and $S_{i}$ is $14 \cdot 16: 4 \cdot 91: 24 \cdot 66$, or $3: 1: 5$. The composition approaches that of a soda phlogopite.

B. B. exfoliates like vermiculite, giving water in the closed tube. In the forceps diffcultly fusible to a dirty gray-white glass. Entirely decomposed by muriatic acid, leaving the silica in pearly scales.

Found in Zillerthal, in Tyrol, associated with chlorite.

238. Asteroite-A name given to a variety of stellate radiated pyroxene, from Nordmark, in Sweden, by L. J. Igelström (B. and H. Ztg. xxix. 8, 1870). It is ash-gray to white in color, has a silky lustre, is opaque, becomes bronze color on exposure. Analysis gave $\ddot{\mathrm{S} i}$ $48 \cdot 48$, Fe $22 \cdot 24$, Mn $4 \cdot 12$, Ca $17 \cdot 00$, Mg $4 \cdot 18$, ignition $2 \cdot 83=98 \cdot 85$. The oxygen ratio of $\hat{R}$ to $\mathrm{Si}$ is $1: 2$. It is a pyroxene near hedenbergite, but containing a portion of the iron replaced by manganese.

415 B. Aquacreptite.-C. U. Shepard, Am. J. Sci. II. xlvii. 256.

Massive, occurring in irregular polyhedral fragments, with flat or concave surfaces. H. $=2 \cdot 5$. G. $=2 \cdot 05-2 \cdot 08$. Lustre dull. Color yellowish-brown. Streak orange-yeilow. Brittle. Adheres to the tongue. Falls to pieces in water, with a crackling noise.

Analyses-1. C. U. Shepard; 2. J. H. Eaton (1. c.):

\begin{tabular}{|c|c|c|c|c|}
\hline $\begin{array}{c}\stackrel{\mathrm{Si}}{\mathrm{i}} \\
\text { 1. } 41^{\circ} \cdot 00\end{array}$ & $\begin{array}{c} \pm 1 \\
4 \cdot 00\end{array}$ & $\underset{17 \cdot 60}{M(g}$ & $\begin{array}{c}\dot{\mathrm{Fe}} \\
13 \cdot 30\end{array}$ & $\underset{23 \cdot 00}{\stackrel{\dot{H}}{1}}=98 \cdot 90$ \\
\hline $43 \cdot 03$ & $5 \cdot 56$ & $19 \cdot 58$ & $12 \cdot 30$ & $17 \cdot 40=97 \cdot 87$ \\
\hline
\end{tabular}

Decomposed by muriatic acid. Found in a vein in serpentine, at Westchester, $\mathrm{Pa}$. It is near hydrophite. Needs further investigation.

732 A. Bastnästte. Huot, Min. i. 296 (1841). Basiskfluorcerium, Hisinger, GEf. Ak. Stockh., 1838, 189. Hamartite, A. E. Nordenskiüld, Ef. Ak. Stockh., 1868, 399.

The so-called basic fluorid of cerium, from Bastnäs, examined by Hisinger, has been reëxamined by A. E. Nordenskiöld, and shown to be a fluo-carbonate. As the name basic fluorid, or hydrofluocerite, conreys an incorrect idea of the composition of the mineral, Nordenskiöld gires it the new name hamartite, overlooking the fact that Huot had already named the mineral bastnäsite, after the locality.

Orthorhombic?-Found in small masses imbedded between allanite crystals. Shows distinct clearage. $\mathrm{H}=4 . \mathrm{G} .=4 \cdot 93$. Lustre greasy. Color wax-yellow.

Composition Ce F+2 (Ce, L̀) $\ddot{\mathrm{C}}=\dot{\mathrm{L} a} 46 \cdot 15$, Ce $3 \cdot 87$, Ce $21 \cdot 12, \ddot{\mathrm{C}} 20 \cdot 20, \mathrm{~F} 8 \cdot 72=100$. Analysis by Nordenskiöld (1. e.)-

$\begin{array}{ccccc}\check{\mathrm{C}} & \mathrm{La} & \stackrel{\mathrm{Ce}}{\mathrm{H}} & \mathbf{F}-\mathrm{O} \\ 19 \cdot 50 & 45 \cdot 77 & 28 \cdot 49 & 1 \cdot 01 & (5 \cdot 23)=100\end{array}$

Nordenskiöld, having shown by direct determination that but 1.01 per cent. water exists in the mineral, and that the balance of loss on ignition is carbonic acid, finds, on recalculating. Hisinger's early results with this correction, a close correspondence with the above, viz., $\mathrm{La}$, $\mathrm{Ce}, 73 \cdot 59, \mathrm{C}, \mathrm{H} 19 \cdot 11, \mathrm{~F}-\mathrm{O}, 5 \cdot 76$, Si $1 \cdot 25=99 \cdot 71$. The direct determination of fluorine by Hisinger gave 9.95 per ct.

In the closed tube gires but little water, hlackens, then becomes whitish-yellow and opaque; also gives a weak reaction for fluorine. Infusible. With acids effervesces slightly. With sulphuric acid gires off fluohydric acid, even after ignition. Found only at the Bastnäs Mine, Riddarhyttan, Sweden. The percentage composition brings this mineral near kischtimite (p, 703). It also resembles kischtimite in some of its physical characters, and further investigation may prove these minerals to be identical. 
Baretite. A name giren by Bombicci to a mineral from Traversella in the province of Irrea. haring the following characters:-Occurs in nodular, radiated, and fibrous masses. $\mathrm{H} .=2 \cdot \mathrm{J} . \quad \mathrm{G} .=2 \cdot 5 . \quad$ Color apple-green. Streak white. Feel soapy. Analysis gave Si $30 \cdot 00$,

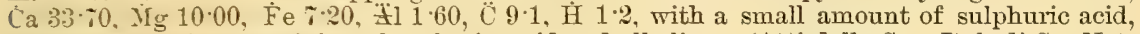
and probably also containing phosphoric acid and alkalies. (Atti della Soc. Ital. di Sc. Nat. xi., in Jahrb. Min., 1868, 750 .

66 A. Berrichite, K. Th. Liebe, Jahrb. Min., 1871, 840.

Hexagonal? Occurring in screw-shaped groups, radiated in structure, the constituent prisms of $\pi$ hich are about $70 \mathrm{~mm}$. long and $8 \mathrm{~mm}$. wide. One terminal plane makes an angle of 81 with the rertical axis; a second, rarer, inclines to the first at an angle of $144^{\circ}$, the angle of the rhombohedron of millerite. Clearage rather perfect parallel to the first of these planes, and no other clearage direction observed, so that the rhombohedral character of the crystals is not certain.

$\mathrm{H}=3-3 \cdot \mathrm{J}, \mathrm{G}=4 . \%$. Lustre metallic. Color lead-gray. Composition $3 \mathrm{Ni} \mathrm{S}+2 \mathrm{Ni} \mathrm{S}^{2}=\mathrm{S}$ $43 \cdot 21$, Ni $56 \cdot 79=100$. An analysis by Liebe gave :

$\begin{array}{ccc}\mathrm{S} & \mathrm{Fe} & \mathrm{Ni} \\ 42 \cdot 86 & 2 \cdot 79 & 54 \cdot 23=99 \cdot 88\end{array}$

B. B. in the closed tube decrepitates and gives a sublimate of sulphur, on charcoal fuses to a brass-rellow magnetic globule. Soluble in nitro-muriatic acid, yielding an emerald green solution.

From Lammrichs Kaul ILine in Westerwald, where it is associated with millerite.

Bixmintrferrite. A. Frenzel. J. pr. Chem., II., iv. 355. This name has been given to a so-called hrpochlorite from Schneeberg, having H. $=1-2$. G. $_{*}=4.47$, and containıng Si 23.08 Fe $: 3 \cdot 3 \cdot 3$. $\dddot{B}_{i} 4 \cdot 26=99 \cdot 6 \%$. Frenzel further distinguishes two varieties of hypochlorite, nufineny-liypochlirite from Bräunsdorf, and bismuth-hypochlorite from Schneeberg; both of these are stated to be mixtures, and not homogeneous minerals.

189. Chrompicotite. T. Petersen, J. pr. Ch., cvi. 137.

A rariety of chromite occurring in rounded octahedrons. $\mathrm{H}=8 . \mathrm{G} .=4 \cdot 115$. Lustre vitreous to greasy. Color black. Analysis by T. Petersen and K. Senfter (l. c.) afforded:

\begin{tabular}{|c|c|c|c|c|}
\hline $\begin{array}{c}\text { Er } \\
56.54\end{array}$ & $\begin{array}{r}A 1 \\
12 \cdot 1\end{array}$ & $\begin{array}{r}\text { Fe } \\
18.0\end{array}$ & $\begin{array}{c}\dot{M} n \\
0.46\end{array}$ & $\begin{array}{c}\mathrm{C} o, \dot{\mathrm{N}} \mathrm{i} \\
\text { tr. }\end{array}$ \\
\hline
\end{tabular}

This composition does not differ much from that of the magnesian alumina chromite from Baitimrore. analyzed by Abich (Anal. 3. 4, p. 153), and that from Lake Memphramagog, examined $3, \mathrm{~F}$ Hunt. If this variety is to have a new name it should have reference to chronite rather than picotite, a magnesia iron alumina spinel with only 7 per cent. of chromic cxril. Its hardness is the chief character which favors its being classed with picotite.

From Dun Mountain, New Zealand.

554 C. Coertleolactite. Coeruleolactin, T. Petersen, Jahrb. Min., 1871, 353.

Cirvto-crystalline to micro-crystalline. Fracture uneven to conchoidal. H.=5. G.= $2 \%-2-5):$ Color milk-white passing into light copper-blue. Streak white. Composition: $\mathbb{A l}^{3}, \mathrm{H}^{2}+10 \mathrm{H}=\mathrm{P} 36 \cdot 74, \mathrm{~A} 139 \cdot 37$, H $23 \cdot 29$. Analysis by Petersen (1. c.) :

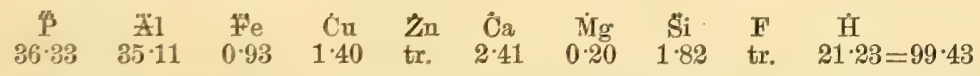

Exs]urling the iron (supposed to exist as limonite), the silica, and copper, lime and magnesia with sufficient phosphrric acid $(=3.27 \hat{\mathrm{P}})$ to make an ortho-phosphate, and calculating the remaining cronstituents $(89.26 \mathrm{p}$. c.) up to 100 we have for the true composition of the minexal. according to Petersen, " 137.04 , Al 39.34, II 23.62, corresponding very closely with the ahrove fromula. B. B. decrepitates, infusible, on charcoal turns reddish-gray. With cobalt sclutirna grives a deep blue. Moistened with sulphuric acid colors the flame green. With the fluzes gives a faint reaction for copper. Soluble in mineral acids, also in fixed caustic alkalies.

From the Rindsberg Mine near Katzenellabogen, Nassau. 
346. Cyanochalcite. R. Hermann, J. pr. Chem., cri. 65.

Massive. H. $=4 \cdot 5 . G_{0}=2 \cdot 79$. Lustre glistening to dull. Color azure-blue. Fracture even and compact. Brittle. Analysis by $\mathbf{R}$. Hermann:

$\begin{array}{cccc}\ddot{\mathrm{S}} \mathrm{i} & \stackrel{\mathrm{P}}{\mathrm{P}} & \mathrm{C} \mathrm{u} & \dot{\mathrm{H}} \\ 26 \cdot 90 & 6 \cdot 95 & 49 \cdot 63 & 16 \cdot 52 .\end{array}$

According to Hermann, this shows the composition to be equivalent to 1 atom of libethenite, and 9 atoms of chrysocolla. It is evidently a substance of like character with the demidoffite of Nordenskiöld. In the tube gives off water and becomes black. With the fluxes reacts for copper. Decomposed by acids without gelatinization.

Occurs at Nischne-Tagilsk.

452. Diabantachronnyn. A name given by Liebe (Jahrb. Min., 1870, 1) to a chlorite-like mineral occurring in the diabase of Voigtland and Frankenwald, and which contributes to the green color of the rock. It is found in seams and clefts, sometimes in amygdules and lining carities in the rock. In some occurrences of diabase it forms the chief binding or cementing material, and is apparently a product of the alteration of the augitic constituent of the diabase. Compact, breaks with a conchoidal fracture, sometimes fibrous. Lustre dull. ('olor greenish-black, in thin splinters chrome-green. H. $=2$. G. $=2 \cdot 81-2 \cdot 93$. Composition, analyses by Liebe:

\begin{tabular}{|c|c|c|c|c|c|c|}
\hline & $\ddot{S i}$ & Al & Fe & $\dot{\mathrm{Fe}}$ & $\dot{\mathrm{Mg}}$ & Ḧ \\
\hline 1. Reinsdorf & $30 \cdot 27$ & $11 \cdot 16$ & & 26.94 & 21.22 & $10 \cdot 20=99 \cdot 79$ \\
\hline 2. Landesf & $29 \cdot 37$ & $12 \cdot 00$ & & $25 \cdot 63$ & $21 \cdot 01$ & $11 \cdot 27=99 \cdot 28$ \\
\hline 3. Höllethal & $29 \cdot 85$ & $9 \cdot 07$ & & $26 \cdot 60$ & $17 \cdot 92$ & $15 \cdot 81=99 \cdot 25$ \\
\hline 4. Trilloch & $31 \cdot 25$ & $10 \cdot 03$ & -47 & $23 \cdot 52$ & $19 \cdot 73$ & $11 \cdot 37=99 \cdot 37$ \\
\hline 5. Gräfenwart (fibrous) & $31 \cdot 56$ & $12 \cdot 08$ & & $21 \cdot 61$ & $22 \cdot 44$ & $11 \cdot 78=99 \cdot 4$ \\
\hline
\end{tabular}

Oxygen ratio for $\hat{\mathrm{R}}, \mathrm{n}, \widetilde{\mathrm{Si}}, \dot{\mathrm{H}}$ in the last analysis is $13.8: 5.8: 16.4: 10.5$. In the closed tube yields water. B. B. turns brown and fuses readily to a grayish-black glass, gives with salt of phosphorus reactions for iron and silica. Soluble in cold muriatic acid with deposition of pure white silica, with nitric acid gires off red nitrous fumes leaving a reddish-brown residue of silica.

113 A. Diapmorite. V. v. Zepharovich, Sitzb. Ak. Wien, lxiii. 130.

In endeavoring to ascertain the cause of the difference of the views of crystallographers in regard to the crystallization of freieslebenite, Zepharovich has discovered that the specimens referred to this species belong to two distinct crystalline systems, although chemically they are identical. He retains the name of freieslebenite for the monoclinic form, and names the new orthorhombic mineral clinplowite. The following planes were observed:

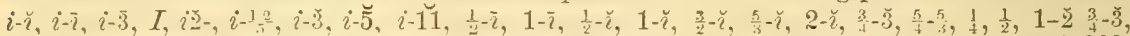
1-4. Cleavage not observed. Fracture uneven to sub-conchoidal. H. $=2 \cdot \tilde{v}-3 . \quad$ G. $=5 \cdot 902$, (Freieslebenite G. $=6 \cdot 35$ ). Lustre metallic. Color steel-gray. Brittle. An analysis of the mineral from Przibram gave Helmhacker (B. and II. Jahrb. xiii. 379) :

$\begin{array}{cccccc}\mathrm{S} & \mathrm{Sb} & \mathrm{Pb} & \mathrm{Ag} & \mathrm{Fe} & \mathrm{Cu} \\ 20 \cdot 18 & 26.43 & 28.67 & 23.44 & 0.67 & 0.73=100 \cdot 12\end{array}$

corresponding closely with the earlier analysis by Payr (this Min. Anal. 4. p. 9气. These analyses Zepharovich refers to diaphorite, as no freieslebenite occurs at Przibram. The pyroguostic characters of both species are the same. Diaphorite occurs at Przibram and Bräzunsdorf exclusively, while at Freiberg it is found with freieslebenite. The name diaphorite was formerly used for an altered rhodonite related to allagite.

503 A. Dorangrte. G. J. Bmish, Am. J. Sci., II. xlviii. 179, Sept., 1869.

Monoclinic. Form of crystal like that of keilhauite (p. 387), omitting $O$ and $-2 i$, and adding $4 i$. Clearage parallel to $I$, distinct, giring $110^{\circ} 10^{\prime}, J$. M. Blake. H. $=\overline{5}$. G. $=$ 3.9.5-4.03. Lustre ritreous. Color bright orange-red. Streak cream-yellow. Analysis, G. J. Brush (1, c.):

\begin{tabular}{|c|c|c|c|c|c|c|}
\hline $\begin{array}{c}\text { Aैs } \\
55 \cdot 10 \\
53 \cdot 22^{3}\end{array}$ & $\begin{array}{c}\stackrel{x 1}{A 1} \\
20 \cdot 68 \\
20.09\end{array}$ & $\begin{array}{l}+e \\
4.78 \\
5.06\end{array}$ & $\begin{array}{l}\dot{\mathrm{Min}} \\
1 \cdot 30 \\
1 \cdot 28\end{array}$ & $\begin{array}{l}\dot{N a} \\
11 \cdot 66 \\
11 \cdot 86\end{array}$ & $\begin{array}{c}\mathrm{Li} \\
0.81 \\
0.70\end{array}$ & $\begin{array}{l}F-0 \\
(5 \cdot 67)=100 \\
\end{array}$ \\
\hline
\end{tabular}

- Too low. 
The orrgen ratio of $\dot{R}, \dddot{H}$ and $\dddot{H}$ is is $3 \cdot 74: 11 \cdot 0 \%: 19 \cdot 16$, or nearly $1: 3: 5$, giving the formula $\left(\frac{1}{4} \mathrm{R}^{3}+\frac{3}{4} \overrightarrow{\mathrm{H}}\right) \mathrm{As}$, in which a portion of the oxygen is replaced by fluorine.

Ir. the ciosed tube blickens at a moderate temperature, but regains its color on cooling; at a higher heat fuses easily to a jellow glass and gives a faint white volatile sublimate, etching the rube slightlr. The same in the open tube, with evolution of acid fumes, reddenirg limms paper. On charcoal, B. B. fuses readily and gives a white sublimate with a strocer arenical odor in R. F. Tith soda and charcoal powder in a matrass yields a sublimate of meenliic arsenic. With the fluxes reacts for iron and manganese. In the forceps fuses at ? giring an intense sola flame. Decomposed by sulplunic acid with evolution of fluohydric acid.

Fonul near Durango in I Iexico. The chemical composition of this mineral places it near aml rgonite. an analogous fluo-phosphate, although the form of duraugite is mounoclinic while amblygonite is triclinic.

35. Pysprisite. T'. Petersen (Pogg. Ann., crxxvii. 3\%7), in a review of the analyses of cirzerasitc. endearors to show that there are two native compounds of antimony and silver,

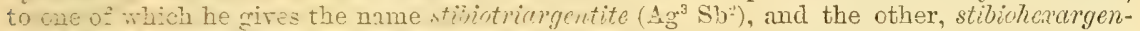

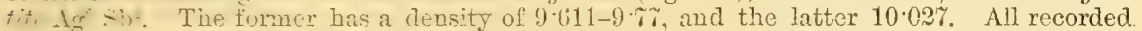
andress that do mot gire one of these formulas he considers either to be erroneous or to. hare been made on a mixture of the above minerals. $18: 1$

617 A. Eosite. A. Shimuf, Min. Beobachtungen, ii. 20, in Sitzb. Ak. Wien, February,

Tetragonal, in minute octahedrons ( $\mathrm{mm}$, diam.) a : b:c=1:3758:1:1. (Basal angle

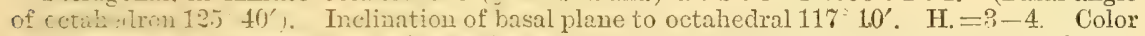
derp aum, red, l,etween that of crocoite and realgar, and much darier than red wulfenite. streak brimish orange-reiluw. Heated in the closed tube clarliens, but regains its color on conling. Fush with bi-su'phate of potash gives a mass which is light yellow while hot, heconis, nn cooling. first redrlish-brown and finally brownish orange-yellow. 'This dissolved in water : il i iroile: with tim-foil colors the solution foint greenish-biue. Not so rapidly acted ui...n in ..mpistic acirl as crocoite or wulfenite. Then a splinter of eosite is placed on a glass fiats, and west with nuriatic acid, with sulsergent arkition of alcohol, and then gently awjumt... it affowis a line to bluish-green coating, with a green precipitate on the edges. Frim is...t; reacti ns, and a series of comparative tests made with crocoite, wulfenite, and vausulit.. Shrouf conchules that eosite is vadarlio-molybrlate of lear. Found implanted in very minute crystals on pyromorphite and cerussite at Leadhills, Scotland.

122 A. Epibotlaygterite. M. Websky, ZS. G. Ges., 1869, p. 747.

Drthrinomlice? orcuming in striaterl prismatic neerlles G. $=6: 309$. Lustre metallic. Color dark biuist gray, almost black. Structuxe granular, acicular. Analyses, 1.2, Websky (1. c.):

$\begin{array}{lcccccc} & \mathrm{S} & \mathrm{Sb} & \mathrm{Pb} & \mathrm{Ni} & \mathrm{Fe} & \mathrm{Zn} \\ \text { 1. Granular. } & 21.89 & 20.77 & 56 \cdot 11 & 0.20 & 0.60 & 0 \cdot 29=99 \cdot 86 \\ \text { 2. Needles. } & 21 \cdot 31 & 20.23 & 54.88 & 0.30 & 0.84 & 1.92=98.88\end{array}$

Websy consirl Is the minoral as probably a product of the decomposition of Boulangerite, from which it riffers in crontaining more sulphur and correspondingly less antimony. Found. with galena, pyrite, blende, and mispickel, at Altenberg in Silesia.

132 A. Errfexite. T. Petersen, Pogg. Ann, cxxxvi: 502, Arsenikkupferwismutherz, Epigenit, Stundberger.

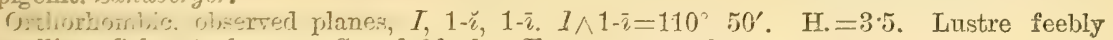
metallic. Color steel-gray. Streak black. Fracture granular.

Composition 6R $\mathrm{S}+\mathrm{As}^{2} \mathrm{~S}^{5}$. Analysis, Petersen (1: c.):

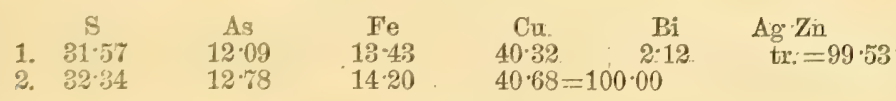

Fr, $2 \mathrm{i}$ Yr, 1 after derlureting the $2 \cdot 12$ Bi which was present as intermingled wittichenite,

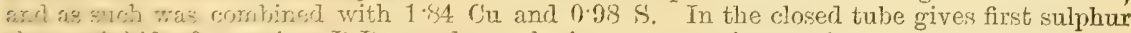
tr.sn wiritis of ar:enir: J3.J3. on charcoal gives an arsenic reaction and a magnetic slag with copper globules. Soluble in nitric acid with separation of sulphur.

Occurs sparingly at Neuglück XIine in Wittichen. 
289. Epiphanite. Igelström, Efv. Ak. Stockh., 1868, p. 29. This name has been given to a chlorite like mineral from Träran in Wermland, Sweden. The composition Igelström found to be $\mathrm{Si} 37 \cdot 10, \AA 121 \cdot 13, \dot{\mathrm{F} e} 20^{\circ} 00, \dot{\mathrm{M} n} \mathrm{tr}, \dot{\mathrm{M} g} 14 \cdot 03$, $\dot{\mathrm{H}} 7 \cdot 83=100 \cdot 09$. It approaches Kenngott's eukamptite (p. 307$)$ and gives the same formula plus one atom of water $\mathrm{R}^{2} \mathrm{Si}+\mathrm{Al} \quad \tilde{\mathrm{S}} \mathrm{i}+2 \mathrm{i}$.

449. Euralite. A name given by F. J. Wiik to a chloritic mineral occurring in seams in clefts of hyperite rock in the parish of Eura, Finland. It is apparently amorphous, but breaks under the hammer into prismatic fragments. H.=2 $5 . \quad G_{.}=2 \cdot 62$. Color dark-green to black. B. B. fuses easily to a magnetic globule. Soluble in muriatic acid. An analysis gave $333 \cdot 68, \dddot{\ddagger} 12 \cdot 15, \dddot{\mathrm{Fe}} 6 \cdot 80, \dot{\mathrm{F}} \mathrm{e} 15 \cdot 66, \dot{\mathrm{M} g} 17 \cdot 92$, Ca $1 \cdot 34, \dot{\mathrm{H}} 11 \cdot 49=99 \cdot 04$. Wiik suggests that this composition is near delessite, which it also resembles in its mode of occurrence. (Jahrb. Min. p. 357.)

474. Ferro-ilmenite, a name given to a variety of columbite from Haddam, Connecticut (Hermann, J. pr. Chem., II. ii. 118).

93 A. Glaucoprrite. F. Sandberger, J. pr. Chem., II. i. 230. Orthorhombic. Planes $i-\bar{\imath}, I, m-\bar{\imath}, \quad H .=4 \cdot 5, \quad G_{0}=7 \cdot 181$. Lustre metallic. Color light lead-gray to tin-white. Streak grayish-black. Composition $\mathrm{Fe} \mathrm{S}^{2}+12(\mathrm{Fe}, \mathrm{Co}, \mathrm{Cu})(\mathrm{As}, \mathrm{Sb})^{2}=\mathrm{S} 2 \cdot 47, \mathrm{As} 69 \cdot 45$, Fe 28.08. Analysis R. Senfter (1. c.) :

$\begin{array}{cccccc}\mathrm{S} & \mathrm{As} & \mathrm{Sb} & \mathrm{Fe} & \mathrm{Co} & \mathrm{C} \mathrm{u} \\ 2 \cdot 36 & 66 \cdot 90 & 3 \cdot 59 & 21 \cdot 38 & 4 \cdot 67 & 1 \cdot 14=100 \cdot 04\end{array}$

In the closed tube gives a sublimate of arsenic with only a small amount of sulphid. B. B. on charcoal gives arsenic fumes with an antimony coating. After roasting yields with soda a magnetic slag with spangles of metallic copper. With the fluxes reacts for iron and cobalt. Decomposed by nitric acid leaving a residue of antimonic acid. Found in the mines of Guadalcanal in Andalusia, Spain. Belongs near Lölingite, p. 77.

Guano Minerals. C. U. Shepard, Rural Carolinian, i. 47\%. The substances described occur in the guano of Guanaje Island, 400 miles north-east of the Chincha Islands.

Guunupite occurs in irregular balls and reins looking like red rock-salt but having a rhombic cleavage. $H .=1-2 . \quad G .=23$. Soluble in $4-5$ pts. of water at $60^{\circ}$. Taste bitter and saline. Analysis gare sulphate of potash $67 \cdot 75$, sulphate of ammonia $27 \cdot 88$, oxalate of ammonia $3 \cdot 7.5=99 \cdot 38$. It loses ammonia on exposure to the air. Heated to redness leares a residue of about 70 pr. ct. of sulphate of potash. It is near Taylorite (p. 614) in composition. Guchormlute is stated to be a pseudomorph of birds' eggs; the specimens are exteriorly white. "and seem to retain portions of the original shell, but these when tested seemed to be a mixture of phosphate and oxalate of lime." Within the substance is foliatcd and has a rhombic cleavage. Color cream white; Instre pearly; translucent. H.=1-2. G. $=1.58$. When heated swells up, turns black, partially fuses, gives off ammonia fumes, and leaves a white residue of sulphate of potash. Composition stated to be sulphate of potash 4020 , oxalate of ammonia $29.5 \%$, water $30 \cdot 46=100 \cdot 23$ - a rery doubtful compound. Oxummite, pluosphummite, and bijhowphummite are other names giren by Shepard for supposed new species consisting of oxalate of ammonia, phosphate of ammonia, and biphosphate of ammonia.

422 A. Güybelite. Fr. von Knhel!, Ber. Ak. München, March 5th, 1870.

In thin, short fibrous layers in clay slate. Color light greenish-white. Translucent. Lustre pearly. Soft and flexible. Analysis, v. Kobell (1. c.) :

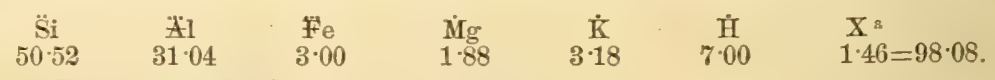

The orrgen ratio of $\hat{\mathrm{R}}, \nVdash, \mathrm{Si}$ and $\hat{H}$ is as $1: 12: 21: 5$, which scarcely leads to a satisfactory formula. In the closed tube yields water. B. B. exfoliates somewhat like pyrophyllite. Fuses at 4 . Not acted upon by acid.

Found at Nordhalben near Steben, in Oberfranken. The composition approaches that of pinite or neurolite (p. 482).

Hullite. A name given br A. R. Leeds to a flexible micaceous mineral of a brown color, occurring in Chester Co., $\mathrm{Pa}$.. and supposed to possess distinguishing optical properties. (Jour. Frank. Inst., III. Ixii. 70.) 
Hamantite. See Bastnaesite.

259 A. Hontonolite. G. J. Brush, Am. J. Sci. II., xlviii. 17., July, 1869.

Orthorhombic. Observed planes $O, i-\grave{\imath}, i-\overline{2}, 1-\bar{\imath}, 1-\grave{\imath}, 1-\overline{2}$ and 1-4 (J. M. Blake, 1. c.), $i-\grave{\imath} \wedge i-\overline{2}$ $=65^{\circ}$ (normals) $1-4 \wedge i-\breve{l}=77^{\circ}-80^{\circ}, i-\breve{\imath} \wedge 1-\overline{2}=69^{\circ}-70^{\circ}$. $i-\breve{\imath} \wedge 1-\breve{b} 40^{\circ} 45^{\prime}$. Acute bisectrix perpendicular to $i-i$, optic axes in a plane parallel to $O$, angle between axes $83^{\circ}-86$, measured in olive oil (J. M. Blake). $\mathrm{H}_{0}=6 \cdot 5 . \quad \mathrm{G} .=3 \cdot 91$. Lustre vitreous, subresinous. Color yellow to rellowish-green, in large masses almost black. Composition $\mathbf{R}^{2} \mathrm{Si}^{\mathrm{i}}$, Analysis, W. G. Mixter (1, c.) :

$\begin{array}{ccccccc}\stackrel{3 i}{\mathrm{Si}} & \dot{\mathrm{Fe}} & \dot{\mathrm{Mn}} & \dot{\mathrm{Mg}} & \dot{\mathrm{Ca}} & \dot{\mathrm{K}} & \text { Ign. } \\ \frac{2}{2} 33.59 & 44 \cdot 37 & 4 \cdot 35 & 16 \cdot 68 & \text { tr. } & 0 \cdot 39 & 0 \cdot 26=99 \cdot 64\end{array}$

B. B. in the open tube and on charcoal becomes dull and magnetic. $F=4$, With the fluxes reacts for iron and manganese. Gelatinizes with muriatic acid.

Found in abundance at the O'Yiel Mine, Orange Co., N. Y., associated with magnetite and calcite. The mineral is a member of the chrysolite group, and is intermediate between hyalosiderite and fayalite.

\section{Hypochlorite. See Bismutoferrite.}

224 A. Ilsemannite. H. Ḧ̈fer, Jahrb. Min., 1871, p. 566.

Crypto-crystalline. Color blue-black to black, on exposure becoming blue. Found imbedded in barite. It is soluble in water, giving a deep-blue solution, and leaving a colorless residue of barite. The solution contained on analysis chiefly a molybdate of molybdic oxyd, and jielded on evaporation deep-blue crystals, which were considered to be the salt Mio + 4 II . which is also supposed to be the composition of the mineral. Ilsemannite is a product of the decomposition of metallic molybdates, and occurs associated with wulfenite at Bleiberg in Carinthia.

431 A. Ivigtite. T. D. Rand, Proc. Acad. Sci. Philad., 1868, 142.

In films and seams in massive cryolite. Granular, approaching micaceous. H. $=2-25$. $\mathrm{G} .=2 \cdot(0.5$. Color pale yellowish-green to yellow (Rand). Also in gold yellow to pale green radiated elastic plates imbedded in cryolite (Hagemann). Analyses: 1. T. D. Rand (1. c.); 2. 3. G. Hagemann, Am. J. Sci., II. xlvii. 133:

\begin{tabular}{|c|c|c|c|c|c|c|c|}
\hline 1. & $\begin{array}{c}\stackrel{\mathrm{S} i}{\mathrm{i}} \\
36 \cdot 49\end{array}$ & $\begin{array}{c}\mathrm{Al} \\
24 \cdot 09\end{array}$ & $\begin{array}{c}\rightleftarrows \mathrm{e} \\
7.54\end{array}$ & $\begin{array}{c}\mathbf{N a}_{1} \\
16 \cdot 03\end{array}$ & $\stackrel{\dot{\mathbf{K}}}{-}$ & $\underset{0.75}{F}$ & $\begin{array}{c}\text { H் } \\
3 \cdot 42\end{array}$ \\
\hline 2. Yellow & $\begin{array}{l}40 \cdot 00 \\
42 \cdot 82\end{array}$ & $27 \cdot 03$ & & $10 \cdot 27$ & 1.05 & tr. & $\begin{array}{l}3 \cdot 06 \\
3 \cdot 03\end{array}$ \\
\hline
\end{tabular}

The loss in To. 1. exclusive of fluorine, is 11.68 per cent., while the average of Nos. 2 and 3 grives a loss of almost 5 per cent. In the closed tułe yields acid water, and B. B. according to Rand fuses easily, while Hagemann states that when free from cryolite it does not fuse. With the fluxes gives iron and silica reactions.

Found with pachnolite and cryolite in the Greenland cryolite. Hagemann's analysis of the green mineral, which he considers the parest variety, gives with the alkalies of No. 2 the oxygen ratio of $\dot{\mathrm{R}}, \underset{\mathrm{H}}{\mathrm{H}}, \mathrm{Si}_{\mathrm{i}}$ and $\dot{H}$ of $1: 6: 8: 1$. Needs further investigation.

520 A. Isoclasite. Isoklas, $F^{\prime}$. Sandberger, J. pr. Chem., II. ii. 125.

Ifrnoclinic. Occurring planes $I, i-i, O$. Planes dull; crystals minute $(10 \mathrm{~mm}$. diam. $)$, Assrociated with pseudomorphic crystals $3.7 \mathrm{c} . \mathrm{m}$. long. Habit columnar. Clinodiagonal cleavage perfect. $H .=15 . \quad G .=2 \cdot 92$. Lustre vitreous to pearly. Colorless to snow-white. Comprosition: Var. 1. fresh crystals; 2. altered mineral, by Köttnitz, 1. c. :

\begin{tabular}{|c|c|c|c|c|c|c|c|c|}
\hline & 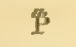 & $\mathrm{Ca}$ & $\dot{\mathrm{M} g}$ & Na & 莸 & $\dot{H}^{(\mathrm{a})}$ & $\hat{\mathbf{H}}^{(\mathrm{b})}$ & Ins. \\
\hline & $\begin{array}{l}29 \cdot 90 \\
34.00\end{array}$ & $\begin{array}{r}49.51 \\
1.00\end{array}$ & 17.30 & 9.80 & $\overline{0.36}$ & $\begin{array}{r}2 \cdot 06 \\
24 \cdot 26\end{array}$ & $\begin{array}{r}18 \cdot 53 \\
9 \cdot 22\end{array}$ & $\begin{aligned} \overline{0.18} & =100 \cdot 0 \\
& =96 \cdot 12\end{aligned}$ \\
\hline
\end{tabular}

The fresh crystals give the formula $\mathrm{Ca}^{3} \mathrm{P}+\dot{\mathrm{C} a \mathrm{H}}+4 \dot{\mathrm{H}}$. Analogous in composition to tagilite, but containing more water. 
In the closed tube both varieties give off neutral water. B. B. the fresh mineral glows and fuses. Soluble in muriatic acid.

Found with hornstone and brown-spar on specimens from Joachimsthal, obtained eighty years ago, and now in the Würzburg Museum.

188 A. Jacobstte. A. Damour, C. R., Ixix. 168.

Isometric, in distorted octahedrons, $\mathrm{H} .=6$ ? (scratches glass). G. $=4.75$. Lustre brilliant metallic. Color deep black. Streak blackish-brown. Magnetic.

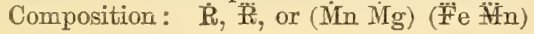

$\begin{array}{ccl}\stackrel{\mathrm{Fe}}{4} & \stackrel{M}{\mathrm{Mn}} & \stackrel{\mathrm{M} g}{\mathrm{~m}} \\ \frac{4}{4} 68 \cdot 25 & 24 \cdot 35 & 6 \cdot 41=99 \cdot 01\end{array}$

As the mineral evolves chlorine feebly when acted upon by muriatic acid, Damour considers a portion of the manganese to exist as 1 in, giving for the true composition of the mineral, in correspondence to the spinel formula, $\dddot{F}$ e $68 \cdot 25$, 프 $4 \cdot 21$, Mn $20 \cdot 57, \dot{M g} 6 \cdot 41=$ $99 \cdot 44$.

B. B. infusible. It does not lose weight when ignited. With the fluxes reacts for iron and manganese. Soluble in muriatic acid, with a slight evolution of chlorine.

From Jacobsberg, in Nordmark, Sweden, where it occurs associated with white mica and native copper in a crystalline limestone.

127 A. JUliante. M. Websky, ZS. G. Ges., 1871, p. 486.

Isometric. Cubic with octahedral and dodecahedral planes. Also dodecahedral. Planes much rounded.

G. $=5 \cdot 12$. Very soft. Lustre metallic-adamantine. Color dark, somewhat reddish leadgray, iron black on exposure. Brittle. Fracture splintery to subconchoidal.

Analysis by Websky (1. c.):

$\begin{array}{cccccc}\mathrm{S} & \mathrm{As} & \mathrm{Sb} & \mathrm{Fe} & \mathrm{Ag} & \mathrm{Cu} \\ 26.50 & 16.78 & 1 \cdot 42 & 0.79 & 0.54 & 52 \cdot 30=98 \cdot 33\end{array}$

Giring a composition almroaching tennantite or enargite. It agrees with the former in crystalline form, but differs in density from both these species.

B. B. Same as temnantite. Found in the Frederick-Julian Mine at Rudelstadt, in Silesia.

121 A. Klaprotholite. Klaprothit, Petersen and Sandberger, Jahrb. Min, 1868, 415. Klaprotholite, G. J. Brush。

This name is giren to the Kupferwismatherz analyzed by Schneider, and recorded in this Mineralogy under Wittichenite, p. 99, anal. 7. Sandberger gives the following characters:Orthorhombic, habit in long furrowed prisms. Planes $I, i-\bar{i}, m-\bar{\imath} ; I \wedge I=107^{\circ}$. Cleavage $i-\bar{\imath}$ rery distinct. In twins, composition-face 1 . Fracture granular. $H_{.}=25$. G. $=4.6$ approx. (Petersen). Lustre metallic. Color steel-gray inclining to yellow, tarnishing brass-yellow. Streak black. Composition, $3 \in \mathrm{Eu} \mathrm{S}+\mathrm{Bi}^{\prime} \mathrm{S}^{3}=\mathrm{S} 19-22, \mathrm{Bi} 55 \cdot 54$, Cu $25 \cdot 21=100$. The mean of three analrses by Petersen gare, on mineral from the Daniel Mline, S 18.66, Bi 5:3.87, Cu $23 \cdot 96$. Fe $1 \cdot \%=98 \cdot 19$. Occurs at many localities in the Black Forest, and distinguished from wittichenite by its distinct clearage, and in its larger content of bismuth. Klaprotholite is generally associated with a cobait-tetrahedrite, while wittichenite is usually found with smaltite. The name klaprothite was given to lazulite by Beudant in 1824, we therefore change Petersen's name to klaprotholite.

483 A. Kocmelite. M. Websky, ZS. G. Ges., xx. 250, 1868.

Tetragonal? In colimmar incrustations passing into rounded, apparently square octahedrous, occasionally showing prismatic planes. Color bromnish isabella-yellow to honeyyellow. Translucent. Lustre dull greasy. H. $=3-3 \cdot 5$. G. $=8 \cdot 7$ t taken on $0 \cdot 1373$ grm.

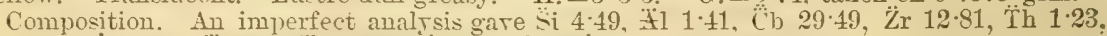
广 $17 \cdot 22, \dot{\mathrm{Ca}} 2 \cdot 10, \ddot{\mathrm{E}} 0 \cdot 43, \overrightarrow{\mathrm{F}} \mathrm{e} 12 \cdot 4 \mathrm{~s}, \dot{\mathrm{H}} 6 \cdot 52, \mathrm{~Pb}$ ? $\mathrm{Xa}$ ? Loss $11 \cdot 82=100$.

In the closed tabe rields water, and the mineral turns reddish. B. B. in the forceps fuses only on the edges to a black glass. coloring the flame yellow. With salt of phosphorus reacts for iron, but in R. F. fuses to a clear bead, showing only a faint reaction for uranium. With soda on charcoal rields a rellowish-white enamel, but no metallic globules, although giving a lead coating oil the coal. Occurs as an incrustation upon a mixtmre of titanic iron and crystals of fergusonite in a coarse grauite in the Kochelwiesen, near Schreiberhau in Silesia.

The composition is mear that of fergusonite, but further investigation is needed. The density is remarkably low for a mineral containing so large a percentage of metallic acids. 
518 A. Kollonkan. This name has been given by Sandberger to a gymnite-like looking smostance found with Sombrero guano. It is a tri-basic phosplate of lime with one atom of water, mired with about $S$ per cent. of carbonate of lime. G. $=270 . \quad H .=5$. J. pr. Chem., II. ii. 129.

641 A. Laxuandite. A. E. Nordenstiöld, Pogg. Ann., cxxxvii. 299, 1869.

Monoclinic. C. $=69^{\circ} 46^{\prime}, \quad a: b: c=1 \cdot 3854: 0 \cdot 7400: 1$. Occurs in wedge-shaped forms with shaip edges. H.=3. G. $=5 \%$. Color dark olive-green to pistachio-green and greenish-grar. Streak pistachio-green. Fracture, crystalline to compact and earthy. Composi-

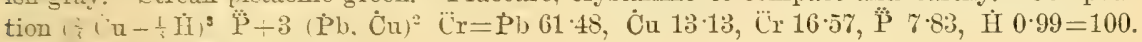
Analyses 1. 2. Nordenskiöld (l. c.) :

\begin{tabular}{|c|c|c|c|c|c|}
\hline 1. $15 \cdot 26$ & $\begin{array}{c}\stackrel{p}{P} \\
8.05\end{array}$ & $\begin{array}{c}\mathrm{Pb} \\
61 \cdot 26\end{array}$ & $\begin{array}{l}\dot{\mathrm{Cu}} \\
12 \cdot 43\end{array}$ & $\begin{array}{l}\text { Fe } \\
1 \cdot 09\end{array}$ & $\begin{array}{c}\dot{H} \\
1 \cdot 31\end{array}=99 \cdot 40$ \\
\hline $16 \% 6$ & 8.57 & $61 \cdot 06$ & $10 \cdot 85$ & $1 \cdot 28$ & $0 \cdot 90=99 \cdot 42$ \\
\hline
\end{tabular}

Hermann has reviewed these results (J. pr. Chem., II. i. 44i), and called attention to the close correspondence of this species in phjsical characters with vauquelinite, and also to the fact that the analyses were made on material from the rery specimens from which Berzelius obtained the vauruelinite. Br assuming that what Berzelius weighed as ehromic acid was really $]_{\text {ih }}$ jhate of chromium, the results of the analysis are made to approximate very closely to tivese of Tordenskijld; and Hermann belieres that laxmannite is probably identical with vauquelinite. But Yordenshiold shows in his investigation that there is associated with laxmannite a chromate free from phosphoric acid corresponding to the vauquelinite of Berzelius.

Hermann has also analyzed a phospho-chromate from Beresof, to which he gives the name jhrsuluelurmite, a mineral resembling luximanite in physical characters, but containing

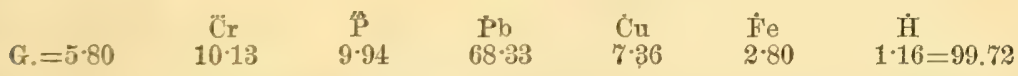

This mineral occurs in rouncterl masses of half a pound weight, made up of globular particles. which exteriorls are covered with small tabular crystals with rounded terminations. It wonld seem prosilble that this argregate might be a mixture rather than a distinet species; and this nar perhaps also lue true in regard to laxmannite. A chromo-phosphate of lead and coppuer from the same locality was described by John (this Min., p. 6:1) as early as 1845 , but was thought to be an impure vauquelinite.

\section{Lime-Wurellite. Kalkwavellit, Kosmann, Z. G. Ges., xxi. 795 (1869).}

This nane has been given to a mineral occurring in concentric radiated spherical and heraispherical agrgegrations. sometimes in acicular crystals, as binding material in phosphorite-breccia; ulso fourd botryoidal and reniform. G. $=245$. Lustre feeble. Color white. Analysis, Kosmann (1. c.):

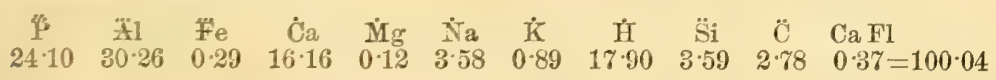

Consillening the carbonic acid to exist as carbonate of lime, and assuming the silica combinerl with the alkalies, Kosmann takes the remainder of the constituents C'a $12 \cdot 62, \mathbb{A l} 30 \cdot 26$,

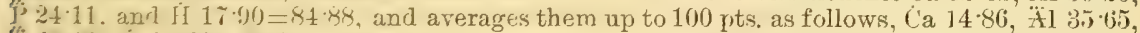
(1) $2 \times \%$. If $21.99=9999$. from which composition he concludes that the mineral is a limewricollite. In the closerd tube yields water. B. B. fuses on the edges. Decomposed by muriatic acid with separation of gelatinous silica.

Folurl with phrsphorite at Dehrn and Ahlbach. Needs further examination to determine its exact chemical composition.

218 D. LuTHropiromite (Breithermpt). A. Frenzel, J. pr. Chem., II. ii. 203 and iv. 3ri3.

This is the substence alrearly noticed hy $\nabla$. Kobell (Ber. Ak. München, Jan. 8, 1870, p. 49) as a lichia mangariess r,e in an examination of a so-called Asholan from Saalfeld. Occurs in fine

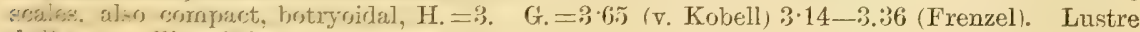
diall tr, matallic. Gelr, r bluish-rjack. Streak blackish-gray. Composition: 1. 2. C. Winckler, J. pr. Chem., II. iจ. 3ธิย. 1872 . 


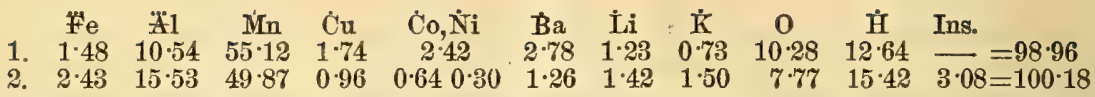

with traces of lime and bismuth. G. of No. $1=3 \cdot 36$, both specimens were from Schneeberg,

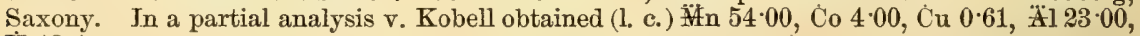
Ḧ 13.4 .

Gives water in the tube. Infusible, colors the flame carmine-red. With the fluxes reacts for manganese; with salt of phosphorus in $R$. F. gives reactions for copper and cobalt. Soluble in muriatic acid with evolution of chlorine.

Found associated with quartz in many localities in the Schneeberg mining district, also occurs at Sayn, and near Siegen. Supposed to be a product of the decomposition of psilomelane. The large percentage of alumina and its content of lithia distinguish it readily from asbolite and lampadite.

598 A. Lüneburgite. C. Nöllner, Ber. Ak. München, 1870, 291.

This name has been applied by Nöllner to a salt from Lüneburg having the following composition: $\ddot{\mathrm{P}} 29 \cdot 8, \ddot{\mathrm{B}} 12 \cdot 7, \dot{\mathrm{Mg}} 25 \cdot 3, \dot{\mathrm{H}} 32 \cdot 2=100$. It also contains $0 \cdot 7 \mathrm{Fl}$. Nöllner gives as formula for this substance $(2 \overrightarrow{\mathrm{Mg}}, \ddot{\mathrm{H}}) \ddot{\mathrm{P}}+\dot{\mathrm{M} g} \ddot{\mathrm{B}}+7 \dot{\mathrm{H}}$. No physical characters are stated.

1 A. Maldonite. G. H. F. Ulrich, Contrib. to Mineralogy of Victoria, 1870, (pamphlet $32 \mathrm{pp} .8$ vo.).

In small particles in quartz, cleavage apparently cubical. H. $=15-2 . \quad$ G. $=8 \cdot 2-9 \cdot 7$ ? (made on less than one grain of impure mineral). Color pinkish-white, but tarnishing on exposure to copper-color and then black. Malleable. An assay by C. Newbery showed the composition to be $\mathrm{Au} 64^{-5}, \mathrm{Bi} 35 \cdot 5$, or nearly $\mathrm{Au}^{2} \mathrm{Bi}$. B. B. fuses easily ; on charcoal coats the coal yellow and yields a globule of gold.

From Nuggety Reef, Maldon.

64 A. Metacinnabarite. G. E. Moore, J. pr. Chem. II. ii. 319 (1870). Am. J. Sci. III. iii. 36.

Amorphous, also found in small apparently isometric crystals, perhaps pseudomorphic. $\mathrm{H}=3 . \quad \mathrm{G} .=7 \cdot 70-7 \cdot 748$. Lustre metallic. Color grayish-black. Streak black, Fracture sub-conchoidal, uneven. Very brittle. Composition: Hg S. Analyses 1. 2., G. E. Moore (1. c.) :

\begin{tabular}{|c|c|c|c|}
\hline $\mathbf{S}$ & $\mathrm{Hg}$ & $\mathrm{Fe}$ & quartz \\
\hline 13.84 & 85.89 & 0.45 & $0 \cdot 24=100 \cdot 42$ \\
\hline
\end{tabular}

Blowpipe characters like cinnabar. Occurs at the Redington Mine, Lake Co., California, with cinnabar, quartz and marcasite. It differs from cinnabar in its amorphous character, in color, streak, specific grarity and lustre, while in these respects it is identical with the black artificial mercuric sulphide of the laboratory.

\section{Mrlarite. A. Kenngott, Jahrb. Min., 1870, 81.}

Hexagonal. Occurring form a hexagonal prism with a plane of a hexagonal pyramid on each angle, and a narrow termination of the lateral edges; observed angle over a terminal edge of the pyramid $144^{\circ} 46 !^{\prime}$ (mean of results), and over a basal edge $74^{\circ} 40^{\prime}$; the latter gives for the former, by calculation, $144^{\circ} 42^{\prime}$.

$\mathrm{H} .=55-6$. Lustre vitreous. Colorless to greenish, resembling the datholite crystals from Bergen Hill. Brittle. B. B. in the closed tube becomes white and gives off water. In the forceps fuses with intumescence to a white blebby glass. In salt of phosphorus slowly but completely soluble to a colorless glass. A partial qualitative analysis gave evidence of the presence of an alkali and besides probably lime. Kenngott considers it a zeolitic hydrous silieate of alumina, lime, and soda, but on uncertain evidence.

Found in Val Milar near Ruäras, Switzerland.

503. Montebrasite. Des Choizenux, C. R. Ixxiii, 306, 1247. L. Moissenet, Ann. d. Mines, VI. xx. 1 (1871). F. Piscmi, C. R. lxxiii, 1479. F. ron Kobell, Ber. Ak, München, Feb. 3, 1872.

This supposed fluo-phosphate from Montebras in France has recently been shown by Pisani and ron Kobell to be identical with amblygonite. Des Cloizeaux found it to be triclinic, with two clearages giving $105^{\prime} 4^{\prime}$, and in the optical examination the bisectrix of the acute angle was positive, while in the Hebrom amblygonite it is negative. Analyses by Moissenet (1), Pisani (2), and v. Kobell (3) afforded: 


\begin{tabular}{|c|c|c|c|c|c|c|c|c|}
\hline $\mathrm{F}$ & $\mathrm{P}$ & Al & Hn & Ća & Ña & $\mathrm{L}_{\mathrm{i}}$ & Si & \\
\hline & 21 & $\begin{array}{l}38 \\
36\end{array}$ & $\overline{0.40}$ & 200 & $\begin{array}{l}6.70 \\
2.58\end{array}$ & . & $2 \cdot 25$ & $1 \cdot 10=102 \cdot 85$ \\
\hline $9 \cdot 0$ & 45.91 & $35 \cdot 50$ & - & 0.50 & $5 \cdot 30$ & $6 \cdot 70$ & 0.60 & $0 \cdot 70-104 \cdot 21$ \\
\hline
\end{tabular}

Pisani's and $\nabla$. Kobell's results give essentially the composition of amblygonite as analyzed by Rammelsberg, and as the physical and pyrognostic characters are also those of amblygonite, there can be no question as to the identity of the Montebras mineral with this species.

Moxzontre. Fr. v. Kobell, Ber. Ak. München, 6 May, 1871.

Compact. H. $=6$. G. $=3$. Color light grayish-green. Translucent on thin edges. Fracture splintery to sub-conchoidal. Resembles green hornstone. Analysis by v. Kobell (1. c.):

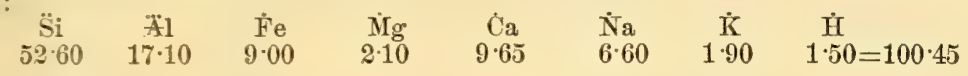

Giving the oxygen of $\hat{R}, \ddot{H}$, and $\ddot{S i}$ as $1: 1: 35$.

B. B. fuses at 3 to a lustrous grayish-green glass. Not decomposed by acids after fusion. For attacked by muriatic or sulphuric acids. Soluble in concentrated phosphoric acid.

Found on the Monzoni MIt. in the valley of Fassa, Tyrol. A microscopic examination of a thin plate of the mineral showed it to be homogeneous.

Ncesnmite. C.W. Blomstrand, EEf. Ak. Stockh., 1868, p. 197.

A chalk-white mineral, from Näsum, Sweden. It occurs mixed with the phosphate attacolite. After calculating out the phosphoric acid as $\mathrm{Al} \mathrm{P}$, the analysis gave $\mathrm{Si} 50.91$, $\mathrm{Al}$

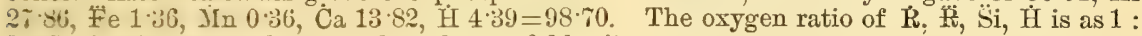
$3: 7: 1$. It may perhaps be elassed near fahlunite.

510. Fadorite. Flkjolot, C. R., Ixxi. 237, 406. F. Pisani, C. R., lxxi. 319; Des Cloizearex, Ann. d. M., VI. xx. 32, 1871.

In flattened tabular orthorhombic crystals, $I \wedge I=132^{\circ} 51^{\prime}$. Cleavage macrodiagonal, vert easy. $\mathrm{H} .=3 . \mathrm{G} \cdot=7 \cdot 02$. Lustre resinous to adamantine. Color smoky-brown to brownish-yellow. Streak yellow. Translucent. Analyses: 1. Pisani (1. c.); 2. Flajolot (1. c.):

\begin{tabular}{|c|c|c|c|}
\hline $\mathrm{Sb}$ & $\mathrm{Pb}$ & 0 & $\mathrm{Cl}$ \\
\hline $31 \cdot 24$ & $51 \cdot 89$ & 814 & $9 \cdot 00=100 \cdot 27$ \\
\hline $32 \cdot 25$ & $51 \cdot 60$ & $8 \cdot 00$ & $8 \cdot 85=100 \cdot 70$ \\
\hline
\end{tabular}

Pisani considers the mineral to correspond to the formula $\overleftrightarrow{\mathrm{Sb} \mathrm{Pb}}+\mathrm{Pb} \mathrm{Cl}$, while Flajolot looks upon it as a compound of oxychlorid of antimony with oxyd of lead. Pisani suggests its analogy with mendipite $2 \mathrm{~Pb}+\mathrm{Pb} \mathrm{Cl}$.

In the closed tube decrepitates and gives a white sublimate. B. B. on charcoal yields an antimony coating and a globule of metallic lead. Added to a bead of salt of phosphorus saturated with copper gives the blue coloration of the flame due to chlorid of copper. Soluble in muriatic acid; also in nitric acid ciluted with tartaric acid.

From Djebel-Nador, in the province of Constantine, Algiers.

214 A. Namaquatrte. A. H. Church, Jour. Chem. Soc., II., viii. 1 (18\%0).

In silky fibres and thin layers. $H .=2 \% . \quad G .=249$. Lustre silky. Color pale-blue. Transparent to translucent. Analysis by Church (1. c.) :

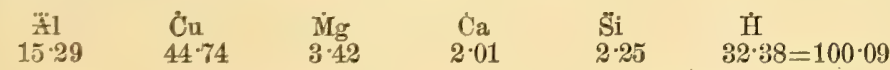

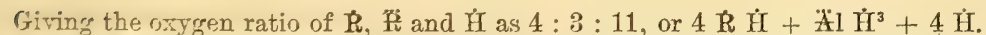

In the closed tube gives off water and turns black. B. B. reacts for copper.

From Lamaqualand, S. Africa. It is analogous in composition to hydrotalcite (p. 178).

146 A. Nixtrixite. An anhydrous sub-chlorid of copper from Nantoko in Chile. Occurs in a copper vein with atacamite and oxydized ores at the surface, while lower down in the vein this arbyrlrous chiorid is found with chalcopyrite and chalcocite. The mineral is white, resernbles serussite in physical characters. It oxydizes on exposure to the atmosphere, and is cronverterl iuts atacamite. W. Hermann considers all atacamite the product of the alteration of nantokite (Breitluapt in B. and H. Ztg. xxvii. 3). 187 Z 
247 D. Nigrescite. F. Hornstein, ZS. G. Ges., 1867, 342.

Amorphous. Fracture uneven and splintery. H.=2. G. $=2845$. Color, when fresh, apple-green; on exposure becomes gray to black ; opaque and earthy, and, on dxying, as light as wac. Loses 16.5 per cent. hygroseopic water.

Analysis :

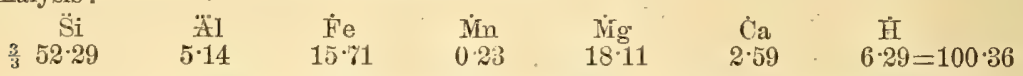

Perhaps the product of the alteration of a nagnesia-iron angite or amphibole.

Found in rounded masses in basalt, at Dietesheim, in the valley of the Maine.

Orileyite. D. Waldie, Proc. Asiatic Society, Bengal, p. 279. September, 1870.

Massive. H. $=5 \cdot 5$. G. $=7 \cdot 34-7 \cdot 42$. Color steel-gray, on fresh fracture with purplish tint. Lustre metallic. Streak dark-gray. Analysis, D. Waldie (1. c.) :

$\begin{array}{cccccc}\mathrm{As} & \mathrm{Sb} & \mathrm{Cu} & \mathrm{Fe} & \mathrm{X} & \text { Insol. } \\ 38.45 & 0.54 & 12 \cdot 13 & 42 \cdot 12 & 6.19 & 0.12=99.55\end{array}$

$\mathrm{X}$, oxydized matters soluble in dilnte muriatic acid $=\mathrm{C}$ n $1 \cdot 21$, $\dot{\mathrm{F}}$ e $1 \cdot 97, \mathrm{~Pb} 1 \cdot 89, \mathrm{As} 1 \cdot 12=$ $6 \cdot 19$. B. B. in the closed tube rields no arsenic. Soluble in nitric acid.

From Burmah, but exact locality not known. Needs further investigation.

Osbornite. -This name has been given by Maskelyne to small gold-yellow octahedrons occurring in augite in a meteorite from Busti, India. It is supposed to be an oxysulphid of titanium and calcium.

\section{Phosphorohromite. See Laxmannite.}

374. Plumbullophane. A name given by Bombicci to a plumbiferous allophane from Monte Vecchio in Sardinia. Occurs in small stalactitic cylinders, rough and opaque on the surface, but interiorly glassy. Color grasish-y cllow with a white streak. H. $=2 \cdot$ j. G. $=19$.

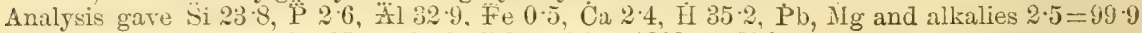
(Atti della Se. Ital, di Sc. Nat. xi., in Jahrb. Min. 1868, p. 750.

40 C. Polmangrrite, F. Sundberger, Jahrb. Min., 1869, 311. T. Petersen, Poger. Ann, cxxxvii. 386. 1869.

Isometric. Observed planes $10 i, m-m$. Cleavage cubic. H. $=2 \cdot 5 . \quad \mathrm{G} .=6 \cdot 974$. Lustre metallic. Color iron-black to dark blackish-gray. Streak black to blackish-gray. Malleable, flattening more under the hammer than argentite.

Composition: $12 \mathrm{Ag} \mathrm{S}+\mathrm{Sb}_{3} \mathrm{~S}_{3}=\mathrm{Ag} \cdot 78 \cdot 16, \mathrm{Sb} 7 \cdot 37, \mathrm{~S} 14 \cdot 47=100 \cdot 00$.

Analysis, Petersen (1.c.):

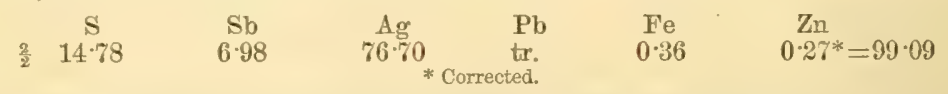

B. B. on charcoal fuses easily to a black globule, giving off antimony fumes, and yielding a brittle globule of silver. Soluble with difineulty in uitric acid with separation of sulphur. Fuming acid dissolves it readily with separation of antimonate of silver.

Occurs at Wolfach in Baden.

The mineral is between argentite and prargrite in composition. If homogenous it would be classified chemically near polybasite; but its isometric form, and the fact that in another analysis Petcrsen found $78.85 \mathrm{Ag}$, suggests that it may possibly be a mixture.

624. Proherite. A. Frenzel, J. pr. Chem., II. iv. 227, 361. 1872

Orthorhornbic. Observed planes $\bar{I}, 0,1-\tilde{n}, m-u$. Cleavage basal. $H .=4 . \quad G .=5 \cdot 91$. Lustre ritreous adamantine. Color reddish-bromn. Streak yeliow. Transhucent to opaque. Composition: $\ddot{\mathrm{Bi}} \ddot{\mathrm{V}}=\ddot{\mathrm{Bi}} 71 \cdot 67 \ddot{\mathrm{V}} 28^{\circ} \mathrm{e} 3=100$. Analyses, 1. 2. Frenzel (1. c.):

$$
\begin{array}{lcc} 
& \dddot{\mathrm{V}} & \dddot{\mathrm{Bi}} \\
\text { 1. } & 27 \cdot 31 & 73 \cdot 39=100 \cdot 70 \\
2 . & 27 \cdot 07 & 72 \cdot 93=100-
\end{array}
$$

In the closed tube decrepitates. B. B. on charcoal fuses and gives a coating of bismuthoxyd, with soda rields a globule of metallic bismuth. With salt of phosphorus a chroruegreen bead in R. F. becoming light yellow in O.F. (vinadium). Soluble in muriatic acid with erolution of chlorine to a deep-red solution, which on dilution becomes green and deposits a yellow basic chlorid.

Tamed pmcherite from the locality, the Pucher Mine, Schneeberg, Saxony. Found associated with bismite and asbolite. 
218 E. Rabdionite. F. von Kobell, Ber. Ak. München, January 8, 1870.

Sialactitic, in colummar or rod-like forms. Very soft, soiling the fingers. G. $=2 \cdot 80$. Lustre cull, after rubbing is greasy to submetallic. Color black. Streak dark-brown. Composition:

\begin{tabular}{|c|c|c|c|}
\hline $\begin{array}{c}\text { 焉e } \\
45 \cdot 00\end{array}$ & $\begin{array}{c}\text { în } \\
13 \cdot 00\end{array}$ & $\stackrel{710}{10}$ & \\
\hline
\end{tabular}

The oxrgen ratio of $\dot{R}: \dddot{\mathrm{R}}: \dot{\mathrm{H}}$ is $1: 3: 2$, and $v$. Kobell writes the formula ( $\mathrm{C} u, \dot{\mathrm{M}} n, \dot{\mathrm{C} o}$ ) $($ Fe, $\forall n)+2 \dot{H}$.

In the closel tube gires neutral water. B. B. fuses at 3 to a steel-gray, magnetic-globule, and colors the flame green. With borax gires a cobalt blue bead. Soluble in muriatic acid with evolution of chlorine, giving an emerald-green colored solution.

From Nischne Tagilsk in Cral. The mineral is near asbolite (p. 181), but differs from it in chemical composition, in containing a large percentage of iron, and in being easily fusible.

163 A. Ralstoxite. G. J. Brush, Am. J. Sci., III. ii. 30. July, 1871.

Irometric. Habit octahedral. Observed planes $1, O$ (this Min. fig. 7, p. 21). H. $=45$. $G .=?+1,02,5$ milligrams). Composition, a hydrous fluorid of aluminum, with possibly small quantities of calcium and sodium.

In the closed tube whitens, yields water at first, then a copious white sublimate which cthes the tulye. The water reacts acid. B. B. on charcoal a faint white sublimate. In the forws whitens, colors the flame yellow, but does not fuse. With cobalt solution gives a ?.-F, blue. In salt of phosphorus dissolves completely to a colorless bead in both flames. S.lulde with efferrescence in a carbonate of soda bead. Decomposed by sulphuric acid with evolution of fluohydric acid.

Occurs with cryolite and thomsenolite at Arksut Fiord, Greenland.

Iirnonite. A name given by C. U. Shepard to a hydrous phosphate of alumina and iron frrm Redinnda. W. I. Found in nodular aggregations. Translucent to opaque. Color grayi-h to sellowish white. H. $=3 \cdot 5 . \quad G .=1 \cdot 90-2 \cdot 07$. Specimen analyzed contained $8 \cdot 8$ per

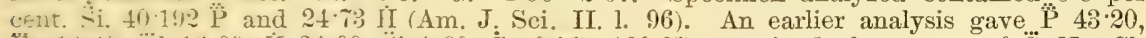

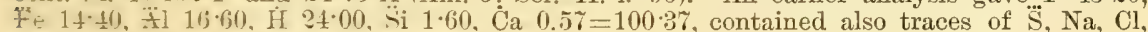
aiml igg. B. B. infusible. Heated with solution of cobalt gives a deep blue color (Am. J. Sci. II. xlvii. 428.

422. Prextrimelite. A name given by A. H. Church (Jour. Chem. Soc., II. viii. 166) to a massive grayish-green agalmatolite-like mineral from Restormel Mine in Cornwall. $\mathbf{H} .=2$.

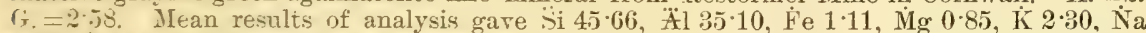
1.39. If $11 \cdot f,=101 \cdot 99$. This composition is near that given by Lehunt and Blythe for killinite (anal. 2!) and 30. under pinite, p. 481). Church does not consider the mineral worthy to rank as a distinct species, but speaks of it as an "immature kaolinite."

261 A. Roepperite. Iron. manganese, zine, chrysolite. W. T. Roepper, Am. J. Sci., II. 1. 35. Roepperite, G. J. Brush. $18 \mathrm{rz}$.

Orthorhombic. observed planes $i-\bar{z}, i-\breve{t}, 1-\bar{\imath}, i-\bar{\imath}, 1-\breve{t}, 1-\overline{4}, O, 2-2, \imath-\overline{2} \wedge i-\overline{2}$ (over $i-\bar{\imath}) 130^{\circ}, i-\bar{z}$ $\left(i-\bar{i}=11, \bar{i} 1-i, 1-i=77^{\circ}\right.$. Cleavage in three directions rectangular, $O$ and $i-\bar{t}$ eminent, $i-i$ splintery, $\quad H .=5 ;-6 . \quad G .=3 \cdot 5,-4 \cdot 08$. Lustre on cleavage planes vitreous to suba larnantine. Color dark-green to black, mottled. In thin splinters translucent and paleyellow crolor. Streak yellow to reddish-gray. Slightly magnetic. Composition: $\dot{\mathrm{R}}^{2} \mathbf{S i}$. $\mathbf{R}$ $=\mathrm{F}$ e, Mn, Zn and Mg. Analyses 1. 2.3., W. T. Roepper (1. c.):

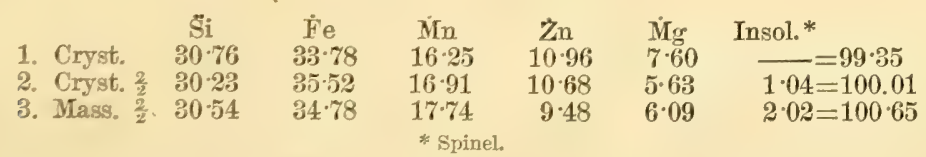

B. B. fuses with rifficulty on the thin edges to a black slag. With the fluxes reacts for irro. mangancse, and silisa ; on charcoal with soda gives a zinc coating. Gelatinizes with arids readily and completely, leaving sometimes a bright-green residue of spinel.

roscurs at Stirling Hill, Sussex Co., N. J., with willemite, franklinite, jeffersonite, and spinel; also found at Franklin Furnace with gahnite. 
393 A. Reissite. A name given by K. v. Fritzsch to a zeolitic mineral from Santorin. According to Hessenberg (his Min. Notizen, No. 9, p. 22) it is orthorhombic with the axial relation for the brachydiagonal, macrodiagonal, and vertical axis. $0.4231: 1: 0 \cdot 2866$. Observerl planes $I, i-\bar{i}, 1-\bar{\imath}, 2-\overline{2}$. Cleavage brachydiagonal. Lustre vitreous. Colorless to white. Fusible with intumescence to a blebby enamel. Gelatinizes with acids more readily after fusion than before. The solution contains lime and alkalies. Hessenberg considers it probable that reissite is identical with Breithaupt's species monophane, and distinct from epistilbite.

125. Rimite. A name given by Brauns to a bismuth-tetrahedrite from Cremenz, Einfischthal in Wallis Canton, Switzerland. It has a conchoidal fracture, an iron-black color, black streak, and greasy-metallic lustre. An analysis gave S $29 \cdot 10, \mathrm{As} 11 \cdot 44$, Sb $2 \cdot 19, \mathrm{Bi}$ $13 \cdot 07, \mathrm{Cu} 37.52, \mathrm{Ag} \mathrm{0.04,} \mathrm{Fe} 6 \cdot 51$, Co $1 \cdot 20=101 \cdot 07$. Found associatad with chalcopyrite. It is worked as an ore of bismuth. The composition places it near annivite, p. 103. ('T. Petersen in Jahrb. Min., 1870, 590).

The name Rimite was used formerly for a supposed selenid of zinc, described by Del Rio, and Riolite for a supposed selenid of silver as well as the preceding, but both names have been dropped from the science, the material on which they were founded being only a mixture.

807 A. Rosthonnite. H. Ḧ̈fer, Jahrb. Min., 1871, p. 561.

In lenticular masses in coal. $G_{.}=1.076$. Lustre greasy. Color brown, with garnet-red reflections: in thin splinters wine-yellow. Composition : $\mathfrak{E}_{2 \downarrow} \mathrm{H}_{40} \Theta$. Analysis by Mitteregger (1. c.):

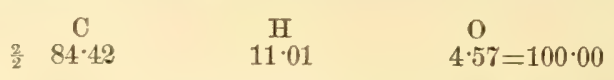

At $96^{\circ} \mathrm{C}$. commences to melt to a riscous brownish-red mass, which at $160^{\circ}$ gives off bubbles and at $205^{\circ}$ white fumes, heated to $225^{\circ}$ the evolution of gas ceases, leaving a thin clark purplish-red fluid. Insoluble in dilute nitric acid as also in potash or alcohol. Slightly soluble in warm cther and entirely so in warm oil of turpentine. Completely soluble in benzole at ordinary temperatures. From Sonnberge, Carinthia. Resembles jaulingite in physical characters, while it is near euosmite in chemical composition.

499. SARcopside. Sarkopsid, M. Webshy, ZS. G. Ges., xx. 245, 1868.

MTonochnic? oceurring in irregular ellipsoids, sometimes in distorted six-sided plates.

H. $=4$. G. $=3 \cdot 692-3730$. Lustre glistening to silky and greasy. Color. on fresh surface, flesl-red to lavender-blue. Translucent in thin splinters. Streak straw-yellow, some grains give a green color. Composition: $4 \hat{\mathrm{R}}^{3} \hat{\mathrm{P}}+(\mathrm{R} F \mathrm{Fl}+\mathrm{H} \hat{\mathrm{H}})$ Websky :

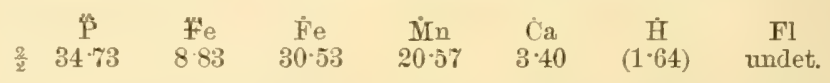

In the closed tube gives water which reacts for fluorine, turns dark-brown and assumes a snb-metallic lustre. Fuses very easily, may be melted to a bead on platinum wire, and this imparts a blue-green color to the onter flame. With the fluxes reacts for iron and manganese, and fused with bi-sulphate of potash in a closed tube reacts for fluorine. coloring brazil-wood paper and etching the tube. Soluble in dilute muriatic and sulphuric acids.

Occurs with vivianite and hureaulite in a granite rein on a ridge between MLichelsdorf and the valler of the Niihlbach in Silesia. This mineral corresponds so.closely to triplite (p. 543) in chemical composition avel prrognostic characters, as also in density and hardness, as to make it exceedingly probable that it may be a variety of that species.

163 B. Sellatte. Strürer, Atti della R. Accad. di Torino, iv. 1868, 35.

Tetragonal, $I$ on $1=12: 30^{\prime}$. $i-i$ on $i-33^{\prime} 161^{-} 34^{\prime}$. Clearage parallel to $I$ and $i-i$ perfect. H. $=5 . \quad$ G. $=: 972$. Lustre vitreous. Fracture conchoidal. Colorless. Transparent. Conposition: $\mathrm{MgF}$ ? In small fragments melts in the flame of a candle with intumescence. Insoluble in water, also in acids. except concentrated sulphuric acid, with this it evolves fluohrdric acid. The sulphuric solution gave $39 \cdot 64 \mathrm{pr}$. ct. of magnesia, which with the other chemical and physical properties of the mineral leads Strürer to consider the mineral a fluorid of magnesium analogous to fluorite in composition.

Found with anhydrite at Geibroula in Piedmont.

659 A. Snoxrite. G. Techmak, Ber, Ak. Wien, Norember Heft, 1869.

Monoclinic. Ratio of orthodiagonal, clinodiagonal, and rertical axis $1: 0 \cdot 7453: 0.5011$; in- 
clination of axis $=\mathrm{C}=101^{\circ} 29^{\prime}$. Observed planes $I, O, i-2,1,1-i . \quad I \wedge T=105^{\circ} 15^{\prime}, 0 \wedge 1-i=146^{\circ}$ ¿'. $0,1=142^{\circ} 5^{\prime}, I \wedge i-2=160^{\circ} 34^{\prime}$. Crystals minute. Also massive. H. $=2 \cdot 5$. G. $=2 \cdot 244$. Color of the massive mineral bluish-green to reddish-yellow. The crystals sometimes colorless and transparent. Taste faint, saline, and bitter. Unaltered on exposure to the air.

Analysis : G. Tschermak (1, c.) :

$\begin{array}{cccc}\overline{\mathrm{S}} & \mathrm{Mg} & \dot{\mathrm{Na}} & \dot{\mathrm{H}} \\ 47 \cdot 17 & 12 \cdot 65 & 18 \cdot 86 & 21 \cdot 82=100 \cdot 50\end{array}$

This rields the oxrgen ratio for $\stackrel{\mathrm{R}}{\mathrm{S}}: \ddot{\mathrm{H}}, 1: 3: 2$ or $\dot{\mathrm{R}} \ddot{\mathrm{S}}+2 \dot{\mathrm{H}}$, the same as the formula given for Blcedite ( 1 . (64:3), which mineral it also resembles in crystalline form. Tschermak remarks that simonyite differs from blcodite in not ethorescing on exposure to air, and losing only a portion of its water $(490 \mathrm{pr}$. ct. $)$ on being heated for two hours in a water-bath. Occurs at Hallstadt.

\pm mineral of the same composition and form, likewise unalterable in air, found at Stassfurth, has been referred by Groth and Hintze to blcelite, these authors assuming that the enlorescence of blcedite, noticed by earlier observers, was due to mixture with some efflorescant salt. ZS. G. Ges. 1871, 870 .

Stibiotriargentite, Stibiohexargentite, see Dyscrasite.

595 A. Stssexite. G. J. Brush, Am. J. Sci., II. xlvi. 140, 240, 1868.

In fibrous seams or reins. $H_{.}=: ; G_{0}=3 \cdot 42$. Lustre silky to pearly. Color white with a tinge of pink or yellow. Translucent.

Composition: (In, $\mathbf{I g})^{2} \dddot{\mathrm{B}}+\mathrm{H}$ or $\left(\frac{2}{3}(\mathbf{I n}, \dot{\mathrm{M} g})+\frac{1}{3} \dot{\mathrm{H}}\right)^{3} \dddot{\mathrm{B}}$. Analysis: G. J. Brush (1. c.) :

$\begin{array}{cccc}\widetilde{\mathrm{B}} & \dot{\mathrm{M} n} & \dot{\mathrm{M} g} & \dot{\mathrm{H}} \\ 31 \cdot 89 & 40 \cdot 10 & 17 \cdot 03 & 9 \cdot 59=98 \cdot 61\end{array}$

In the clnsed tube darkens in color and yields neutral water. If turmeric paper is moistened with this water. and then with dilute muriatic acid, it assumes a red color (boric acid). In the forceps fuses in the flame of a candle $(\mathrm{F}=2)$, and $\mathrm{B}$. B. in $\mathrm{O}$. $\mathrm{F}$. yields a black crystalline mas. coloring the flane intensely yellowish-green. With the fluxes reacts for manganese. Soluble in chlorhydric acid.

Found on Jine Hill. Franklin Furnace, Sussex Co., N. J., associated with franklinite, zincite, willemite, and other manganese and zinc minerals. This species approaches in composition the mineral szaibelyite.

T.acosite. $r_{f}$. H. F. Thich, Contributions to the Mineralogy of Victoria, Melbourne, 1870 (pamphlet of 32 pp. 8vo.).

In thin seams and threads with scaly structure, the scales apparently rhombic plates. H. $=1-2 . \quad G_{0}=2 \cdot 46-2 \%$. Lustre pearly. Color silver-white, faint greenish, or yellowish. Scales tlexible but not elastic. Resembles talc. Analyses 1. 2 by C. Newbery (1. c.):

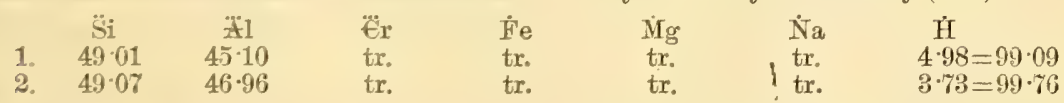

The oxvgen ratio of anal. 1 for $\dot{H}, \mathfrak{A l}, \ddot{\mathrm{i}}$ is $1: 5: 6$. This mineral is perhaps related to selwynits. with which it occurs. and also to westanite (described in this appendix).

Ob̌s. From Mount Ida near Heathcote, Victoria.

Tellurwismuthsilber. C. Rummelsberg, ZS. G. Ges., xxi. 81.

Granular. $G .=\tau \cdot 80$ ?. Lustre metallic. Color gray, tamished. Cuts with a knife, but sufficiently brittle to be readily pulverized. Composition : analysis by Rammelsberg, 1. c. :

$\begin{array}{ccccl}\mathrm{S} & \mathrm{Te} & \mathrm{Bi} & \mathrm{Ag} & \mathrm{Cu} \\ 3 \cdot 32 & 24 \cdot 10 & 48 \cdot 50 & 23-35 & \text { tr. }=99 \cdot 27\end{array}$

Pammelst)erg gives the relation of $\mathrm{S}: \mathrm{Ag}: \mathrm{Bi}:$ Te as $1: 2 \cdot 08: 2 \cdot 24: 1 \cdot 8$, but thinks it may be more conectly expressed by $1: 2: 2: 2$, as the bismuth obtained was not free from tellinim and the fromula of this new tellurium mineral may then be written $\mathrm{Ag}^{\prime} \mathrm{S}+$ Pi- Te or $A-S+2$ Bi Te?. He also questions whether the mineral may not be a mixtnre of aresstite and tellurirl of hismuth, or of native silver and sulphotelluxid of bismuth, rot. finds rothing in the physiral properties of the mineral to indicate a mixture.

Obs. From Sierra de Tapalpa, Mexico. 
817 A. Trinkerite. G. Tschermak, J. pr. Chem., II. ii. 258, and Jahrb. G. Reichs., $1870, x x .279$.

Compact and amorphous. $H_{0}=15-2, G_{0}=1 \cdot 025$. Lustre greasy. Color hyacinth-red to chestnut-brown. Transparent to translucent. Analysis, 1. Hlasiwetz (1. c.);2. Niedzwiedzki, Jahrb. Min., 1871, 641 :

$\begin{array}{lccccc} & \dot{\mathbf{C}} & \mathbf{H} & \mathrm{S} & \mathbf{O} & \text { Ash } \\ \text { 1. Carpano } & 81 \cdot 1 & 11 \cdot 2 & 4 \cdot \mathrm{y} & 3 \cdot 0 & \text { None }=100 \\ \text { 2. Gams } & 81 \cdot 9 & 10.9 & 4 \cdot 1 & 3 \cdot 1 & -\end{array}$

Fuses at $168^{\circ}-180^{\circ} \mathrm{C}$, at a higher temperature gives off choking fumes. Insoluble in water, and only slightly in alcohol and ether. Soluble in hot benzole.

Occurs in large compact masses in brown coal at Carpano near Albona in Istria ; also found at Gams near Hieflau in Styria. Resembles in composition the tasmanite of Church (p. 746).

573 B. Trögerite. A. Weisbach, Jahrb. Min., 1871, 870.

Monoclinic, in thin tabular crystals. Cleavage perfect, parallel to the broad tabular plane. G. =33. Lustre on the clearage-plane pearly. Color lemon-yellow. Composition, $\dddot{\Psi}^{5} \ddot{A s}^{2}$ + 20 II (Winckler). No analysis is given. Oceurs with walpurgite and other uranium minerals at the Weisser Hirsch Mine in Neustädtel near Schneeberg, Saxony.

Uranotrl, E. Boricky, Jahrb. Min., 1870, 780.

Orthorhombic, in acicular crystals. Occurring form $I, i=\check{i}, m-\grave{\imath}$; angle of prism $I$ about 164 (Zepharovich). In radiated or stellated groups. Cleavage probably basic. G. $=3 \cdot 9595$. Color lemon-yellow. Streak lighter. The mean of three analyses gave Boricky:

\begin{tabular}{|c|c|c|c|c|c|}
\hline S̈i & $\ddot{E}$ & ※l & Ca & $\ddot{\mathrm{P}}$ & 亡் \\
\hline $13 \cdot 78$ & $66 \cdot 75$ & 0.51 & $5 \cdot 27$ & 0.45 & $12 \cdot 67=99 \cdot 43$ \\
\hline
\end{tabular}

Giving a composition near that of uranophane (p. 805). It also resembles it in crystalline form, the angle of prism $I$ of uranophane $146^{\circ}$, giving $162^{\circ}$ for the prism $i-\overline{2}$.

B. B. tums black. Solul)le in warm muriatic acid with separation of flocky silica.

Found with fluorite, uranite, and quartz at Wölsendorf, Bavaria.

622 B. Vanadiolite. Hermann, J. pr, Chem., II. i. 445.

Form not determined. Occurs in small crystals, partly in druses. Color dark-green, almost black, in small fragments dark emerald-green. Streak grayish-green. Lustre vitreous, brilliant. G. $=3 \cdot 96$. Analysis gave

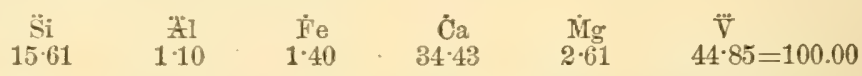

which Hermann considers as representing a compound of three atoms of augite, and one of sulbramadate of lime. He gives for this the formula $3 \mathrm{R} \quad \mathrm{Si}+\left(\mathrm{a}^{6}\left(\nabla \mathrm{O}^{4}+2 \mathrm{VO}^{5}\right)\right.$. B. B. fuses to a black slag with caulitlower-like intumescences. With salt of phosphoms gives a darkgreen head, and a silica skeleton. Decomposed on fusion with a mixture of carbonate of socia and nitre. From Slüdünka near Lake Baikal associated with lavroffite.-A substance containing as this does orer 70 per cent. of a vanadate, with the balance a silicate corresponding to argite can scarcely be looked upon as a homogeneous simple mineral. It is here classed with the vanadates.

573 A. Walpurgite. Walpurgin, A. Weisbach, Jahrb. Min., 1871, 870.

Monoclinic, in thin scaly crrstals. G. $=5 \cdot 8$. Lustre adamantine to greasy. Color pome-

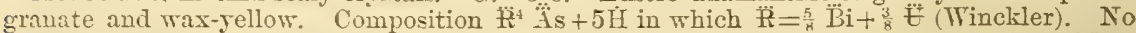
analysis is giren. Occurs with trögerite and other uranium ores at the Weisser Hirsch Mrine in Neustädtel near Schneeberg, Sarony.

323 A. Westaxite. C. W. Blomstrand, Ef. Ak. Stockh, 1868, p. 197, in J. pr. Ch., cr. 311 .

In radiated crystalline massea, sometimes in prismatic erystals. H. $=25$. Color brickred. An analysis gave:

\begin{tabular}{|c|c|c|c|c|}
\hline $\begin{array}{c}\stackrel{\ddot{\mathrm{Si}}}{ } \\
(42.53)\end{array}$ & 51:14 & $\underset{1 \cdot 15}{\stackrel{4}{P}}$ & $\begin{array}{c}¥ 0 \\
1 \cdot 01\end{array}$ & $\underset{4 \cdot 17}{\stackrel{\dot{\mathrm{H}}}{4}=100 \cdot 00}$ \\
\hline $42 \cdot 91$ & & & 1.56 & - \\
\hline
\end{tabular}


This composition is near wörthite, a hydrous fibrolite, but it differs from that mineral in inferior hardness.

B. B. swells up; infusible and turns white. Not acted upon by acids.

Associated with pyrophyllite at Westana, Sweden.

601 A. WIxkworThtтe, H. How, Phil. Mag., April, $18 \% 1$.

In imbedded nodules, crystalline on fracture. Glistening. Colorless to white. Translucent. $\mathrm{H}_{\mathrm{o}}=2-3$. Composition: analyses 1. 2., H. How, 1. c. :

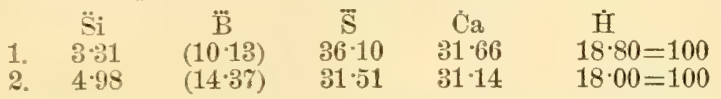

In the closed tube gives water. B. B., decrepitates and fuses readily to a clear bead, coloring the flame green; on continued blowing froths, becomes opaque and no longer shows the green coloration.

Found in gTpsum at Tinkworth, Nova Scotia. How considers No. 1 to be represented by $11 \mathrm{ia}, 1 \mathrm{i}, 9 \stackrel{\mathrm{S}}{3} \ddot{\mathrm{H}}$ and $20 \dot{\mathrm{H}}$, while $\mathrm{No} .2$ is the same with substitution of $8 \dddot{\mathrm{S}}$ and $4 \ddot{\mathrm{B}}$. He sugrests that the mineral is intermediate between selenite and howlite. May it not be a mixture?

92 A. Wolfachite. F. Sandberger, Jahrb. Min., 1869, 313.

T. Prterxrk. Pogro. Anm. cxxxrii. 39\%. Orthorhombic, in small erystals coating niccolite Onserved planes $I_{\text {. w }}$. . $\quad \mathrm{H},=5.5 . \quad \mathrm{G} .=6.3 \% 2$. Lustre metallic. Color silver-white to tinwhite. Streak black, Analysis by Petersen (1. c.):

$\begin{array}{cccccccc}\mathrm{S} & \mathrm{As} & \mathrm{Sb} & \mathrm{Pb} & \mathrm{Ag} & \mathrm{Fe} & \mathrm{Ni} & \mathrm{Co}, \mathrm{Cu}, \mathrm{Zn} \\ 14.43 & 38.46 & 13.17 & 1.32 & 0.12 & 8 \cdot 71 & 29 \cdot 53 & \overbrace{\text { traces }=100.74}^{10}\end{array}$

The lead and silver were believed to be due to a small amount of intermingled galena and drscrasite. The results give the formula $\mathrm{Ni} \mathrm{S}{ }^{2}+\mathrm{Ni}$ (As Sb) ${ }^{2}$ exactly the same as given for the isometric cortuite (p. if), showing this compound to be dimorphous. Corynite has a

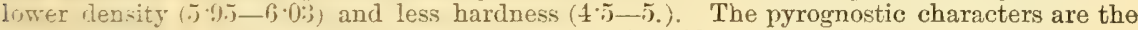
same for both minerals and both are soluble in nitric acid. From Wolfach in Baden.

\section{E. Wollongongite, S. Sittiman, Am. J. Sci., II. xlviii. 85.}

This name has been riven prorisionally to a hydro-carbon from New South Wales. Occurs in cutical blocks. without lamination. Fracture broad conchoidal. Color greenish to brownish-black. Lustre resinous. Translucent in thin shavings, showing under the microscope an amber-yellow light.

Alone in the tule rines not melt but decrepitates and gives off oil and gas. Ignites readily and rields. when heated rut of access of air, $82 \%$ volatile matter, coke 6.5 , and when burned 11. (1) jeI cent of ash. Insoluble in ether and benzole, but slightly acted upon by bi-sulphid of carbon.

550 A. Zephapotichte. E. Brricky, Sitzb. Ak. Wien, lix, 593, 1869.

Crystalline to compact, horn-like in aspect. $H_{0}=5.5 . \quad G_{0}=2 \cdot 3 \%$. Color greenish, yellowish or grayish-white. Translucent. Fracture conchoidal. Composition:

\begin{tabular}{|c|c|c|c|c|c|c|}
\hline P & ¥1 & fe & Ća & Mg & Ḧ & Quartz \\
\hline $35 \cdot 56$ & 29.177 & & $1 \cdot 07$ & 0.41 & $26 \cdot \%$ & $5 \cdot 46=98 \cdot 97$ \\
\hline $37 \cdot 46$ & $28 \cdot 44$ & m & 0.54 & tr. & $26 \cdot 57$ & $6 \cdot 05=99 \cdot 06$ \\
\hline $37 \cdot 80$ & $29 \cdot 60$ & 0.85 & $1 \cdot 38$ & - & $28 \cdot 98$ & $0.46=99.07$ \\
\hline
\end{tabular}

Trs. 1 and 2 contained intermingled wavellite, and No. 3 an earthy gibbsite. Boricky thirk the gaalyses prove the mineral to be essentially a phosphate having the formula $\mathbb{A}$ $f=f H$. and that in analysis 2 this phosphate is mixed with $\frac{1}{17}$ of wavellite, while in No. 5 is aserciaterl with of gibbsite and 3 of tribasic phosphate of lime. The formula (jII liffers from Ciallainite (p. 572) only in containing 1 atom more of water, and analysis 2 ,

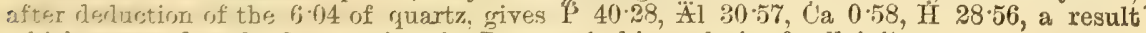
which arrorraches the firures given by Damour in his analysis of callainite.

Occurs in sandstone at Trenic in Bohemia. 


\section{Notes on a few previously described species.}

198. Brookite. A. Schrauf announces that his recent crystallographic studies have proved brookite to be monoclinic and isomorphous with wolframite (Jahrb. Min., 1871, 163).

636. Caledonite. Schrauf has found this species to be monoclinic in crystallization. He makes $a \wedge m=132^{\circ} 32^{\prime}$, and $a \wedge c=90^{\circ} 30^{\prime}, a, m, c$, being the planes so lettered in Miller's Mineralogy, and corresponding, $a$ to $i-\bar{t}, m$ to $I$, and $c$ to $O$, in this work. (Jahrb. Min., 1871, 374.)

Ephesite, see Lesleyite below.

24. Diamond. P. v. Jeremejew has discovered minute crystals of diamonds irregularly distributed through plates of xanthophyllite from the Sehischimskian Mountains near Slatoust. They are readily recognized when magnified 30 diameters, and with 200 diameters their crystalline form is seen to be that of the hexa-tetrahedron $3-\frac{2}{3}$ combined with the tetrahedron, the first four being distinctly conrex, while the tetrahedral plane is flat (like fig. 59 p. 21, except that there are also small flat tetrahedral planes). MIost of the crystals are colorless. They are symmetrically disposed in their matrix, their trigonal intermediate axes being vertical to the foliation of the xanthophyllite. The green plates of this mineral, nearest the rounded masses of the talcose slate and serpentine enclose umusually large numbers of them and they are likewise found in the two rocks themselves. Jahrb. Min., 1871, p. 275 in Am. J. Sci., III, iii. $5 \%$.

Lesleyite. The mineral named lesleyite by I. Lea (see p. 800 ) has been analyzed by S. P. Sharples (Am. J. Sci., II. xlvii. 319) and J. L. Smith (ib. xlviii. 254). Sharples examined two varieties, one white (anal. 1), and the other red (anal. 3). Smith analyzed the white mineral (anal. 2).

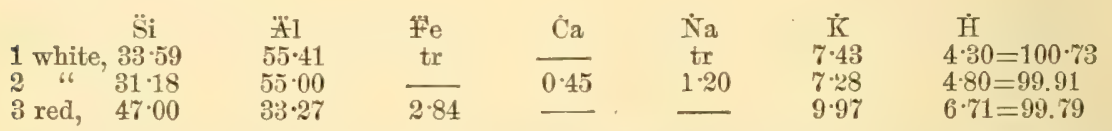

The analysis of the red rariety was made under Sharples's direction by C. IV. Roepper. It is an entirely different substance from the white mineral, and was properly referred to pinite by Sharples.

Smith compares the composition of the white variety with that of his ephesite (see Min., p. 507) of which he gives the following new analysis.

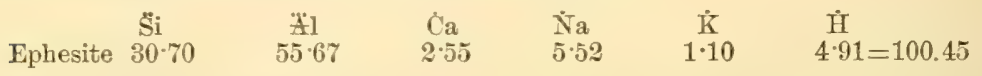

There is also a rery close correspondence in the physical as well as in the chemical characters of the two minerals, and they are evidently closely related. Lesleyite is found associated with diaspore and both minerals have a peculiarity in regard to their hardness that suggests a want of homogeneity. They are easily scratched with a knife, but they hoth contain particles which scratch topaz. Under the magnifier they both present glistening scales which are soft and apparently micaceous. It is evident that the minerals are mixtures of corundum and probably diaspore with a mica similar to the damourite found at the lesleyite locality; and that the foliated soft mineral is damourite or a hydrous mica near that species.

Prttersonite. This substance, classed temporarily under the mica group in the supplement to this mineralogr (p. 801), has been analyzed by S. P. Sharples with the following results (Am. J. Sci, II. xlvii. 309).

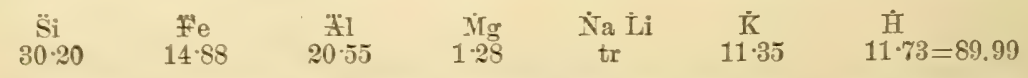

The potash is stated to have been determined by the difference (loss), but the analysis foots up, exclusire of the potash, only $78.6 \pm$ leaving $21: 36$ for potash instead of 11:35. This large error runs through the calculated oxygen ratios, and hence is not typographical. In view of it, the analrsis leals to no satisfactory conclusion. The percentages of silica, iron, alumina and water are very near those of prochlorite. 
463. Slrynite. Ulrich now regards this species as belonging to the pinite group (Contrib. Min. Victoria, p. 24).

98. Sylernite. Schranf's recent crystallographic researches makes this species orthoThumbic in crrstallization. He says that he has observed the twius described by Kokscharof; aml that the augles and planes are given rightly by Miller; and that he has observed 17 new planes. (Jahrb. Min., 1871, 394.)

Trinymith. This new rariets of silicic acid, discovered by v. Rath (1). 805, this Min.) in Mexican porphry, has been found in many localities in Europe; it is especially well characterizer in the trachyte of Drachenfels and in the orthoclase-porphyry of Waldböckelheim.

610. Whifmmite. Des Cloizeaux has shown that this species is monoclinic in crystallization. C. R. Lxix, 868 . 



.50 


